\title{
Theoretical Investigations on Mapping Mean Distributions of Particulate Matter, Inert, Reactive, and Secondary Pollutants from Wildfires by Unmanned Air Vehicles (UAVs)
}

\author{
Nicole Mölders',2, Mary K. Butwin'1,2, James M. Madden",2, Huy N. Q. Tran1,3, \\ Kenneth Sassen ${ }^{1,4}$, Gerhard Kramm1,5 \\ ${ }^{1}$ Geophysical Institute, University of Alaska Fairbanks, Fairbanks, USA \\ ${ }^{2}$ Department of Atmospheric Sciences, College of Natural Science and Mathematics, University of Alaska \\ Fairbanks, Fairbanks, USA \\ ${ }^{3}$ Bingham Entrepreneurship \& Energy Research Center, Utah State University, Vernal, USA \\ ${ }^{4}$ Department of Atmospheric Science, University of Utah, Salt Lake City, USA \\ ${ }^{5}$ Engineering Meteorology Consulting, Fairbanks, USA \\ Email: cmoelders@alaska.edu
}

Received 26 August 2015; accepted 20 September 2015; published 23 September 2015

Copyright (C 2015 by authors and Scientific Research Publishing Inc.

This work is licensed under the Creative Commons Attribution International License (CC BY). http://creativecommons.org/licenses/by/4.0/

(c) (7) Open Access

\section{Abstract}

Evaluated Weather Research and Forecasting model inline with chemistry (WRF/Chem) simulations of the 2009 Crazy Mountain Complex wildfire in Interior Alaska served as a testbed for typical Alaska wildfire-smoke conditions. A virtual unmanned air vehicle (UAV) sampled temperatures, dewpoint temperatures, primary inert and reactive gases and particular matter of different sizes as well as secondary pollutants from the WRF/Chem results using different sampling patterns, altitudes and speeds to investigate the impact of the sampling design on obtained mean distributions. In this experimental design, the WRF/Chem data served as the "grand truth" to assess the mean distributions from sampling. During frontal passage, the obtained mean distributions were sensitive to the flight patterns, speeds and heights. For inert constituents mean distributions from sampling agreed with the "grand truth" within a factor of two at $1000 \mathrm{~m}$. Mean distributions of gases involved in photochemistry differed among flight patterns except for ozone. The diurnal cycle of these gases' concentrations led to overestimation (underestimation) of $20 \mathrm{~h}$ means in areas of high (low) concentrations as compared to the "grand truth." The mean ozone distribution was sensitive to the speed of the virtual UAV. Particulate matter showed the strongest sensitivity to the flight patterns, especially during precipitation. 
Keywords

WRF/Chem, Wildfire Smoke, Unmanned Aircraft Vehicles, Theoretical Flight Design, CALIPSO

\section{Introduction}

In recent years, unmanned air vehicles (UAVs) have attained increasing attention from environmental scientists as UAVs permit measurements in hazardous air space (e.g. over wildfires) and/or over difficult to access remote areas [1] (e.g. Interior Alaska). The reasons are manifold. UAVs are much cheaper to purchase and deploy than manned aircrafts. In addition, the logistics for a UAV flight campaign have much shorter timeframes than planning an aircraft field campaign. This fact is especially critical in the research on phenomena that occur irregularly (e.g. volcanic eruptions) and for applications.

Over the last decades, communities in the boreal taiga have grown, and they are expected to grow further in the future [2]. In the sparsely populated, but wildfire-prone boreal taiga, a dense air-quality monitoring network would be required to provide public health advisory on smoke rolling into town from upwind wildfires. A recent study [3] showed that a network would require randomly distributed sites to provide the most representative data distribution. The installation and maintenance of such networks over the length of a fire season are expensive, especially in difficult to reach places. Furthermore, data are only required in case of a wildfire in a community's upwind region. This means data demand exists on an irregular basis over a limited area far outside of town and for a limited time. Performing measurements by flying UAVs in hard to reach or inaccessible regions may be cheaper than installing and maintaining a monitoring network in complex, permafrost-underlain, undeveloped terrain.

Due to its continental location, Interior Alaska summers are dry and warm with calm winds. Most of its summer precipitation is from convection and thunderstorms [4]. Thus, this region is prone to wildfires [4]-[7]. Due to the low population density [2], the road network is sparse. Any existing (meteorological) sites are biased to the road system consisting of one south-north highway and three west-east highways over an area as large as $20 \%$ of the contiguous US. Due to this remoteness, barely any monitoring of air quality exists outside the city limits of the Fairbanks metropolitan area, which is the only conurbation in Interior Alaska. Thus, this conurbation could benefit from UAV measurements for air-quality advisory when wildfires exist in its upwind [8].

In atmospheric sciences, UAVs have been deployed for measuring meteorological fields. A recent study [9], for instance, evaluated the atmospheric boundary layer (ABL) parameterizations of the advanced research Weather Research and Forecasting (WRF) model [10] for calm and gravity-wave conditions by UAV-collected temperature, relative humidity and wind profiles up to $3 \mathrm{~km}$ altitude above ground. The UAV has shown its value for examining the temporal evolution of the ABL including mesoscale features like subsidence inversions. The authors concluded that UAVs have the potential to close the observational gap for investigating relevant physical processes like mountain-induced gravity waves in the ABL. During the Verification of the Origins of Rotation in Tornadoes Experiment 2 (VORTEX2), for instance, UAVs took in-situ measurements in the rear flank downdraft and gust front to examine the thermodynamics in the lifecycle of super cells [11].

In geology, some studies focused on volcanic heat and gas emissions [12] [13]. One study, for instance, used a UAV at La Fossa Vulcano, Italy during April 2007 for the remote sensing of sulfurdioxide $\left(\mathrm{SO}_{2}\right)$ fluxes by ultraviolet and infrared spectrometers, and for measuring the carbondioxide $\left(\mathrm{CO}_{2}\right)$ to sulfurdioxide ratio. This study focused on the temporal rather than spatial aspect of the release.

In the above studies, the UAVs collected data over a small area and for phenomena that lasted comparatively short in time (e.g. formation of inversion, downdraft, gust front) and/or with the purpose of research. However, when the intent is to use data for air-quality advisory and to fly UAVs instead of installing and maintaining a monitoring network, it has to be examined whether UAVs can provide reliable mean spatial distributions of air-quality relevant quantities. Air-quality advisory namely relates to the National Ambient Air Quality Standard (NAAQS) that is defined for time ranges of $1 \mathrm{~h}$ to $24 \mathrm{~h}$ depending on the pollutant [14]. Furthermore, application of UAVs in air-quality advisory requires several hours for data collection to cover the area in the downwind of a wildfire in the upwind of a settlement. Furthermore, some of the chemical species undergo reactions thereby altering the chemical composition of the propagating smoke plume. 
Our feasibility study examined whether UAVs could provide the spatial distributions of air-quality relevant information desired for air-quality advisories. To achieve our goal, we turned to numerical modeling and applied the analysis method by [3] described in Section 2. In our study, evaluated model data from a wildfire simulation served as a dataset representative of wildfire-smoke conditions ("grand truth") from which a virtual UAV sampled data. Section 3 presents an evaluation of the model data. In Section 4, the mean distributions derived from the sampled data were compared to the mean distribution according to the model data, which served as "grand truth." Here, the sensitivity of mean distributions derived from sampled data to three different flight patterns, at three different heights and at three different speeds is discussed. The conclusions end with recommendations for setting up UAV flight plans.

\section{Experimental Design}

\subsection{Reference Data "Grand Truth"}

\subsubsection{Model Setup}

To investigate the impact of UAV flight patterns, speeds and altitudes on temporal mean spatial distributions derived from the sampled data, we ran WRF/Chem [15] [16] with the advanced research WRF dynamics solver [10] to obtain a four-dimensional physico-chemically consistent high-resolution dataset. We used the following physical and chemical packages. The Rapid Radiative Transfer Model [17] served to determine long-wave radiation under consideration of multiple absorption bands of atmospheric trace gases and cloud optical depth. The Goddard shortwave scheme [18] calculated diffuse and direct solar radiation under consideration of the ozone and cloud properties calculated inline [16].

A modified version of the Grell-Dévényi cumulus ensemble scheme [19] served to parameterize the impacts of the multiple mass fluxes from sub-grid scale convective clouds on the vertical profiles of temperature, moisture and wind. Cloud microphysical processes on the resolvable scale considered co-existance of super-cooled water (rainwater, cloud water) and ice, graupel and snow [20]. Interaction of clouds, radiation, and chemistry were considered as in [21] [22].

The processes in the ABL were parameterized using the Eta model Mellor-Yamada-Janjić schemes [23] [24]. These schemes, among other things, calculated the turbulent kinetic energy, buoyancy and shear in the ABL and free atmosphere.

The Rapid Update Cycle land-surface model [25] determined the exchange of momentum, heat, and matter at the Earth-atmosphere interface. It predicted the soil temperature, and soil water/ice conditions at six depths under consideration of frozen ground physics. Furthermore, it considered a one-layer canopy, fractional snow cover, snow depth, snow temperature and snow density, as well as surface albedo.

The gas-phase chemistry mechanism [26] considered 14 stable species, four reactive intermediates and three abundant stable species for inorganic chemistry, 26 stable species and 16 peroxy radicals for organic chemistry. The photolysis rates for 21 photochemical reactions were calculated inline as a function of wavelength, temperature, species, and absorption cross-section [27]. Dry deposition of trace gases followed [28] with the modifications for Alaska by [29].

The Modal Aerosol Dynamics for Europe [30] [31] calculated aerosol physics. Herein, the particle-size distribution from the submicron to coarse mode was parameterized by two log-normal modes in accord with [32]. The Secondary ORGanic Aerosol Model described the secondary aerosols formation by low volatility processes and gas-to-particle conversion [33]. Aerosol-removal processes by sedimentation and washout as well as some aqueous phase reactions were considered [16].

\subsubsection{Emission Data}

Emissions from biomass burning were created with the so-called PREP-CHEM-SRC emission processor [22] [34]. Information on the locations and daily advancement of fires stemmed from the Moderate Resolution Imaging Spectroradiometer (MODIS) wildfire database [35]. Emission rates and species depended on fuel maps [36] and area burned [16].

Anthropogenic emissions were generated from the Emission Database for Global Atmospheric Research (EDGAR) emission inventory, which provides annual emissions of greenhouse and precursor gases on a $1^{\circ} \times 1^{\circ}$ grid [37]. Emissions of $\mathrm{SO}_{2}$, nitrogenoxides $\left(\mathrm{NO}_{\mathrm{x}}=\mathrm{NO}+\mathrm{NO}_{2}\right.$, i.e. nitric oxide and nitrogen dioxide), carbonmonoxide (CO), particulate matter of $2.5 \mu \mathrm{m}$ or less in diameter $\left(\mathrm{PM}_{2.5}\right)$ and $10 \mu \mathrm{m}$ or less in diameter $\left(\mathrm{PM}_{10}\right)$ as 
well as volatile organic carbons (VOC) were allocated depending on the weekday, and hour of the day using Alaska-specific allocation functions [38]. The split for $\mathrm{PM}_{2.5}$ and VOCs followed [29].

Biogenic emissions were calculated inline depending on land-use/cover following [39] [40]. Furthermore, this scheme included NO emissions by soil bacteria as a function of soil conditions.

\subsubsection{Simulations}

The model domain of interest covered the atmosphere over Interior Alaska centered at $65.57^{\circ} \mathrm{N}, 145.9^{\circ} \mathrm{W}$ with $110 \times 100$ grid-points of $4 \mathrm{~km}$ increment to $100 \mathrm{hPa}$ (Figure 1). The initial and boundary conditions were downscaled from the $1^{\circ} \times 1^{\circ}$ and $6 \mathrm{~h}$ resolution global final analysis data [41] of the National Centers for Environmental Prediction.

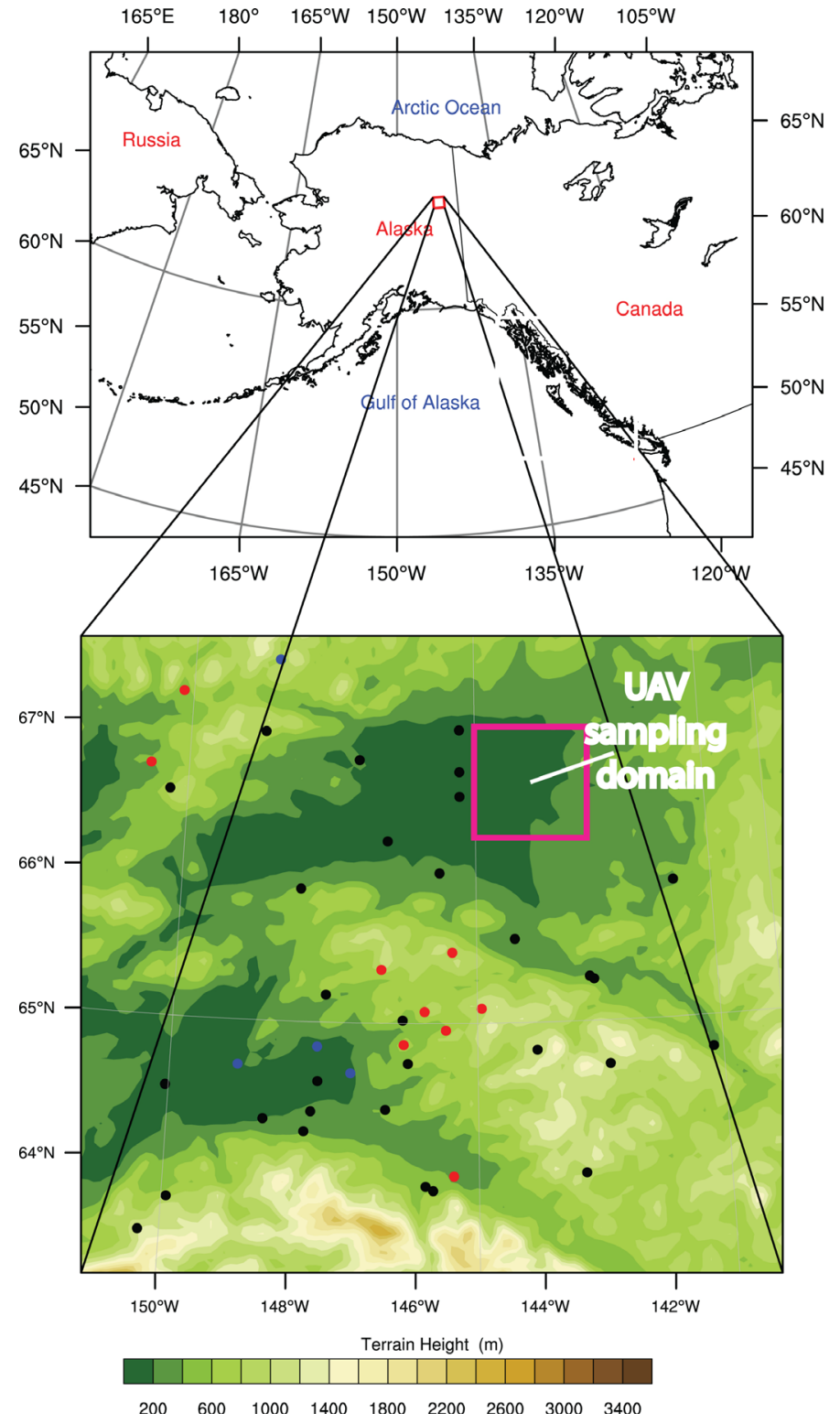

(a)

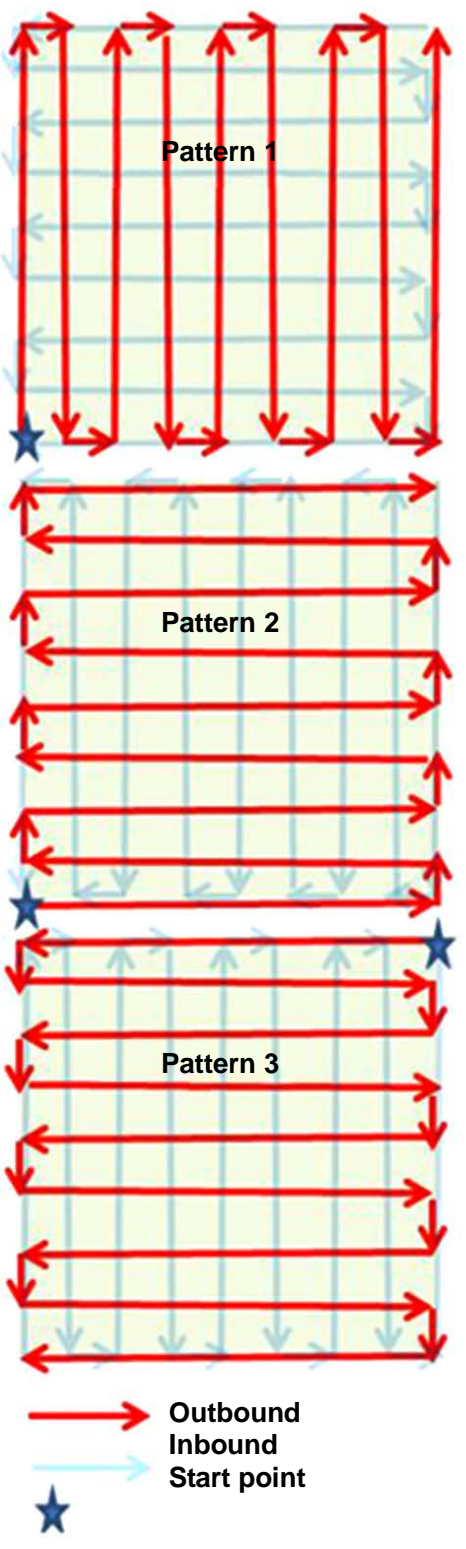

(b)

Figure 1. (a) Location of the WRF/Chem domain on which the evaluation was performed with location of the area sampled by the virtual UAV (magenta box). The black, blue, and red dots indicate the locations of the surface meteorological sites from the RAWS, ASOS, and SNOWTEL network, respectively; (b) Flight patterns for sampling by the virtual UAV. 
The simulation started on August 3, 20090000 UTC with Alaska background concentrations. The chemical concentrations from the first two days of the simulation were excluded from the UAV sampling to allow for spin-up of the chemical fields. WRF/Chem was run in forecast mode for August 3 to 10, 2009. The meteorology was re-initialized every five days, while the chemical fields of the previous day served as initial data for the next.

\subsubsection{Evaluation}

To assess whether the WRF/Chem data represented a realistic dataset, we used data from 33 surface meteorological sites. The performance in predicting $2 \mathrm{~m}$ air temperatures, $2 \mathrm{~m}$ dewpoint temperatures, $10 \mathrm{~m}$ wind speeds and directions was quantified in terms of bias (simulated vs. observed), root-mean-square error (RMSE), standard deviation of error (SDE), and correlation-skill score (R).

Data of $\mathrm{PM}_{2.5}$ from three sites in the Fairbanks metropolitan area served to assess WRF/Chem's performance in capturing the temporal evolution in this area and in case of 1-in-3-days data, the order of magnitude. We omitted calculation of spatio-temporal means for the following reasons: (a) All data were from the same area in the domain. (b) In this area, notable anthropogenic emissions occurred which was not the case anywhere else. (c) Too few data existed for a meaning full statistic. (d) Our study focused on wildfire smoke.

To assess the performance in predicting the height and vertical extension of the smoke plume, cross-sections of WRF/Chem predicted $\mathrm{PM}_{10}$ were compared qualitatively to Cloud-Aerosol Lidar and Infrared Pathfinder Satellite Observations (CALIPSO) level 1B backscatter and depolarization data. We used the backscatter data to assess orientations, sizes, and shapes of aerosols through the linear depolarization ratio (LDR) following [42][45]. The LDR is a ratio of backscattering powers in the perpendicular to parallel polarization planes [42].

In the interpretation of the CALIPSO data, we used the same considerations and thresholds as [46] [47]. In theory, perfectly spherical particles show no backscattering in the perpendicular, or orthogonal plane, while irregular shapes cause perpendicular backscattering [43] [48]. Generally, smoke particles are spherical [49] producing near zero perpendicular backscatter and marginal depolarization [50] [51]. Fresh smoke and smoke layers at high altitudes in the troposphere show depolarizations of $3 \%$ and $5 \%$, respectively [48]. Aged smoke yields slightly elevated depolarization values because of coagulated particles and/or included soil particles [49] [52]. The upper parts of smoke layers have depolarization values of around $6 \%$, while comparatively lower depolarization exists below this layer [50] [53]. Irregular-shaped particles like smoke particles cause some orthogonal backscatter [54].

\subsection{UAV Virtual Sampling}

The Crazy Mountain Complex fire of 2009 served as a testbed (Figure 1). While August 5 showed a fully developed smoke plume, August 6 presented a case wherein the passage of a cold front removed the smoke. August 7 to 10 permitted us to examine the rebuilding of the wildfire-smoke plume [8].

Following [3], the evaluated WRF/Chem data served to represent the atmospheric conditions during a wildfire event. These data are referred to as "grand truth" hereafter. The virtual UAV assumed in this study was a Scan Eagle. The Scan Eagle has a cruising speed of $111 \mathrm{~km} \cdot \mathrm{h}^{-1}$ and a theoretical flight time of $24 \mathrm{~h}$ without payload. Since any load including fuel reduces flight duration, we assumed $20 \mathrm{~h}$ flight duration as the best-case scenario. The virtual UAV sampled air temperature, dewpoint temperature, $\mathrm{CO}, \mathrm{SO}_{2}, \mathrm{NO}, \mathrm{O}_{3}, \mathrm{PM}_{2.5}$ and $\mathrm{PM}_{10}$ from the model data using the different flight designs described below.

The area that the virtual Scan Eagle can cover within $20 \mathrm{~h}$ of sampling encompasses about $60 \mathrm{~km} \times 60 \mathrm{~km}$ [8]. We applied the flight patterns as in [8]. The default flight pattern (FP1) was flying at cruise-speed at $200 \mathrm{~m}$ altitude. Herein the UAV started at 0000 UTC in the southwest corner of the sampling domain flying $60 \mathrm{~km}$ north then turning east for $4 \mathrm{~km}$, turning south for $60 \mathrm{~km}$, and again turning east for $4 \mathrm{~km}$ (Figure 1). The virtual UAV repeated this pattern until it reached the northeast corner of the sampling domain. Then the virtual UAV flew 60 $\mathrm{km}$ west, $4 \mathrm{~km}$ south, $60 \mathrm{~km}$ east, $4 \mathrm{~km}$ south and so on until reaching its original start point. Flight pattern 2 (FP2) assumed the same starting point, but with the long west-east/east-west scans first followed by the long south-north/north-south scans. The third flight pattern (FP3) started in the northeastern corner of the sampling domain flying the long south-north/north-south legs first followed by the long west-east/east-west legs. Three different velocities were examined: stall speed $\left(72 \mathrm{~km} \cdot \mathrm{h}^{-1}\right)$, cruise-speed $\left(111 \mathrm{~km} \cdot \mathrm{h}^{-1}\right)$, and maximum speed $\left(148 \mathrm{~km} \cdot \mathrm{h}^{-1}\right)$. Sampling occurred at $200 \mathrm{~m}, 500 \mathrm{~m}$ and $1000 \mathrm{~m}$ height. These heights correspond to the lowest 
level safe for UAVs traveling over the complex terrain of Interior Alaska, a level located in about the middle of the ABL and in the upper/around the top of the ABL, respectively. Since for air-quality advisory purposes the $200 \mathrm{~m}$ level is of greatest interest, the discussion of results mainly focused on this height.

The authors are well aware that sampling frequency, i.e. the number of readings per time unit, differ among instruments for the various quantities mentioned above. For simplicity of our theoretical investigations, we assumed a frequency of one reading per second for all instruments mounted on the virtual UAV.

Since the WRF/Chem output data were recorded at one-hour intervals on a lattice with 4 km increment, the sampled quantities were interpolated in time and space between available WRF/Chem data. The field quantities were collected under consideration of the UAV's speed and wind speed as a distance-time weighted mean between the values at the grid-cell in which the UAV was located and the nearest grid-cells along the flight path, and between the values of the past and next WRF/Chem recording at these grid-cells. A grid-cell was sampled for the duration that the UAV flew in the grid-cell. Consequently, more data were collected within a grid-cell where the UAV faced headwind than in a grid-cell with tailwind. For instance, at zero wind speed and cruise speed, for a grid-cell that is not located at the boundaries of the $60 \mathrm{~km} \times 60 \mathrm{~km}$ sampling domain, about 130 data were collected on the outbound and inbound paths each, i.e. in total 260 data. As it is obvious from Figure 1, for the grid-cells at the boundaries of the sampling domain, the UAV collected data on the short legs as well. This means these grid-cells were sampled four times ( 2 times $4 \mathrm{~km}$, and 2 times $2 \mathrm{~km}$ ). The grid-cells at the corners of the sampling domain were sampled four times for $2 \mathrm{~km}$ each. In the above example of zero wind speed, the virtual UAV would collect about 390 and 260 data, respectively.

Based on all the data sampled during the flight, a $20 \mathrm{~h}$ mean was calculated for the $60 \mathrm{~km} \times 60 \mathrm{~km}$ sampling area. Furthermore, based on all data sampled within $20 \mathrm{~h}$ in a $4 \mathrm{~km} \times 4 \mathrm{~km}$ grid-cell, a $20 \mathrm{~h}$ mean was calculated for each grid-cell to obtain the $20 \mathrm{~h}$ mean distribution within the sampling area. Such $20 \mathrm{~h}$ distributions were calculated for each day from August 5 to 10 for each sampled quantity.

We compared these distributions to the distribution of $20 \mathrm{~h}$ means calculated from the WRF/Chem data ("grand truth"). Differences in chemical field quantities were expressed in terms of normalized mean bias (NMB), and fractional mean bias (FB) in accord with [55] [56]. The latter weights positive and negative biases equally, while the former avoids inflation due to the range of observed concentrations [56].

In case of flying at maximum and stall speed, the UAV finished sampling the area in less and more than $20 \mathrm{~h}$, respectively. In the plots, we showed the mean distributions obtained for sampling at different speeds no matter of how long it took the virtual UAV to cover the entire sampling area. Thus, be aware that plots show $20 \mathrm{~h}$ mean distributions for all sampling designs except the minimum and maximum speed scenarios. In the calculation of the statistics, we used sampled and "grand truth" $20 \mathrm{~h}$ mean distributions no matter whether the entire domain was already sampled (in case of stall speed) or sampling took less than $20 \mathrm{~h}$ (in case of maximum speed).

\section{Results and Discussion}

\subsection{Evaluation}

Capturing the meteorology is central to air-quality forecasts [57]. In the evaluation, we considered all data available in the WRF/Chem domain to demonstrate that WRF/Chem provided a realistic four-dimensional consistent dataset of an Interior Alaska wildfire.

The obtained skill scores have similar magnitude as those of other WRF studies in high latitudes [7] [58] [59]. In our study, WRF/Chem captured the temporal evolution of $2 \mathrm{~m}$ temperature acceptably (Figure 2(a)). The overall bias, RMSE, SDE, and correlation-skill score were $2.7^{\circ} \mathrm{C}, 4.9^{\circ} \mathrm{C}, 4.1^{\circ} \mathrm{C}$ and 0.74 , respectively. The diurnal course was dampened by about $3^{\circ} \mathrm{C}$. Both minimum and maximum temperatures were higher than observed, i.e. the model atmosphere was overall too warm. The spatial variability of simulated $2 \mathrm{~m}$ temperatures was less than observed due to the smoothing of the landscape by use of a grid-cell mean terrain height and dominant land-cover and soil type. These assumptions have impact on the flux densities of heat, and water vapor and hence temperature and the formation of convective clouds [60] [61].

WRF/Chem captured the temporal behavior of $2 \mathrm{~m}$ dewpoint temperatures acceptably (Figure 2(b)) with overall bias, RMSE, SDE and correlation skill score of $\sim 0^{\circ} \mathrm{C}, 3.6^{\circ} \mathrm{C}, 3.6^{\circ} \mathrm{C}$, and 0.70 , respectively. These performance skills fall in the range of other subartic WRF studies [7] [59] [62] [63].

On average over all sites, WRF/Chem captured the temporal evolution of $10 \mathrm{~m}$ wind speed acceptably (Figure 2(c)). At the beginning of the simulation, gusts related to thunderstorms, channeling effects and 


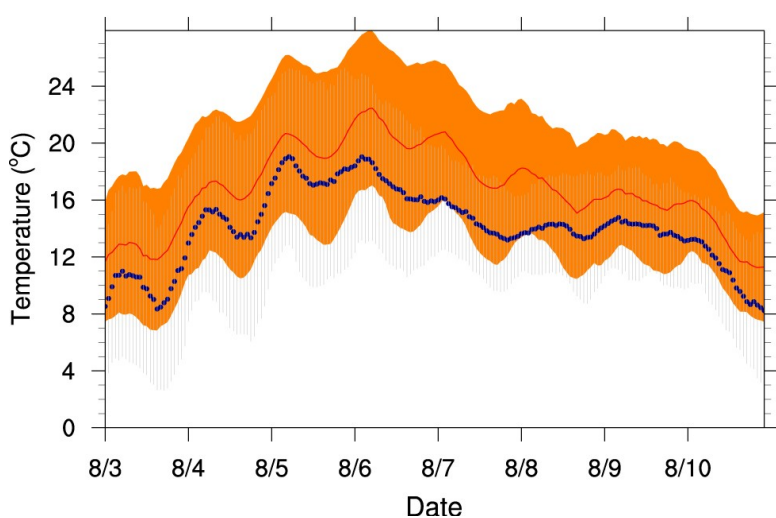

(a)

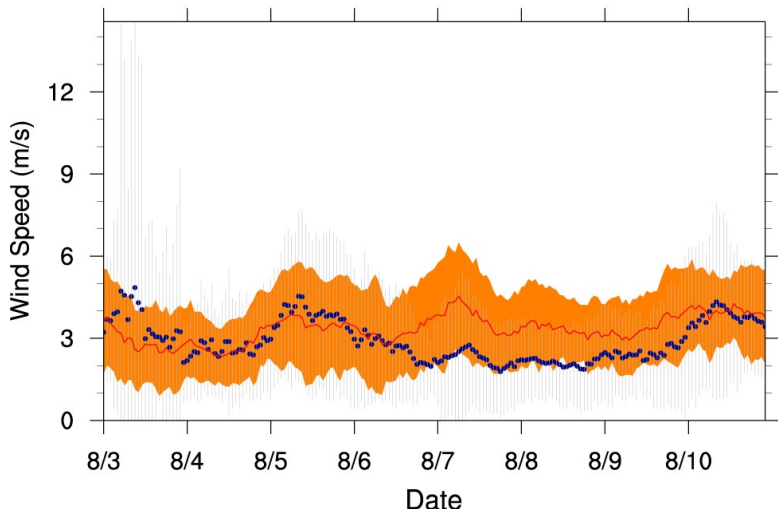

(c)

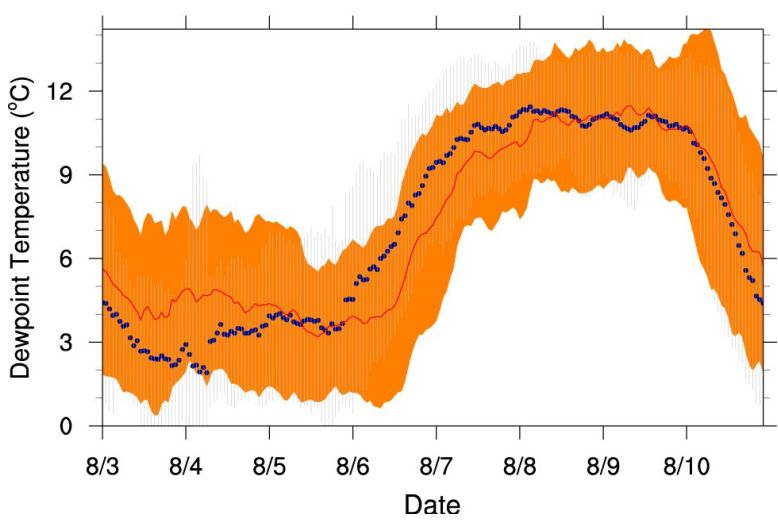

(b)

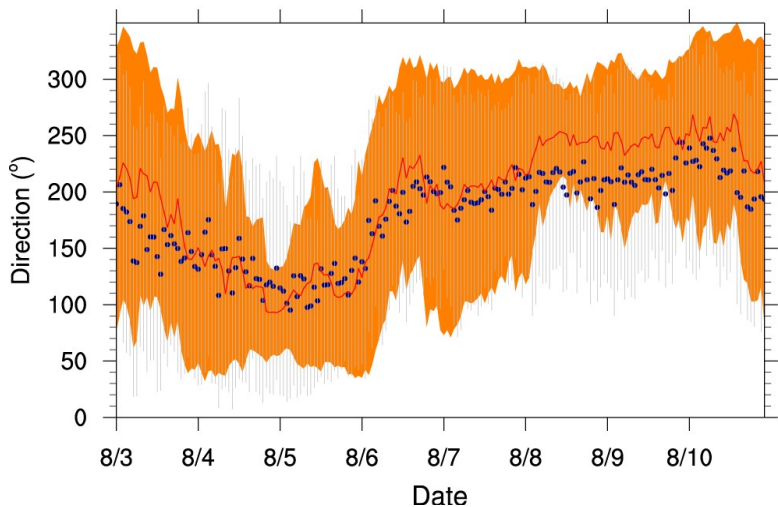

(d)

Figure 2. Spatial means and spatial standard deviations of hourly (a) $2 \mathrm{~m}$ air temperatures, (b) $2 \mathrm{~m}$ dewpoint temperatures, (c) $10 \mathrm{~m}$ wind speeds, and (d) $10 \mathrm{~m}$ wind directions as obtained from WRF/Chem (red line and orange shading, respectively) and the observations (blue dots and gray bars, respectively) using all sites with available data.

fire-related winds led to huge variability in observed wind speeds. During frontal passage, simulated and observed wind speeds were slightly offset, but agreed better in magnitude than during calm conditions. WRF/ Chem overestimated $10 \mathrm{~m}$ wind speeds during the stagnant conditions in the middle of the episode. Overall, these shortcomings yielded a positive bias of $0.1 \mathrm{~m} \cdot \mathrm{s}^{-1}$ with RMSE and SDE of $6.2 \mathrm{~m} \cdot \mathrm{s}^{-1}$ and low correlation.

The complex terrain caused the high variability of wind directions (Figure 2(d)) as the valleys channel the wind. Furthermore, mesoscale circulations also affected wind direction. In the model, valleys were of subgrid scale for which the spatial variability in wind direction was about a factor of two smaller than according to the observations. WRF/Chem best captured wind direction between August 5 and 8 and showed too strong westerly component otherwise.

Simulated $\mathrm{PM}_{2.5}$ at the State Office building in Fairbanks showed similar general temporal behavior as the observations (Figure 3). However, simulated concentrations were much smaller in magnitude than observed. Due to errors in temporal offsets canceling each other out, mean fractional bias and normalized mean error amounted to $10 \%$ and $20 \%$, respectively. The average fractional difference was $42 \%$. The discrepancies were partly due to offsets in the wind direction and/or the overestimation of wind speed. Based on these limited data WRF/Chem performed for the Fairbanks metropolitan area acceptably. Unfortunately, with daily data from just one site and 1-in-3-days data from just three sites (of which one site coincided with the site of daily data) a more thorough analysis is impossible.

The episode was relatively cloudy (e.g. Figure 4) and clouds attenuated the lidar signals. Thus, only few cases existed where the lidar reached the smoke in the ABL. The qualitative comparison with these CALIPSO lidar curtains suggested that WRF/Chem acceptably simulated the locations of particulate matter in the ABL. On some days, offsets occurred in the horizontal position of the smoke plumes. These discrepancies can be explained by the timelag between the WRF/Chem cross-sections and the overestimation of wind-speeds. The offsets were of similar magnitude as those found by [47] in another subarctic study. 


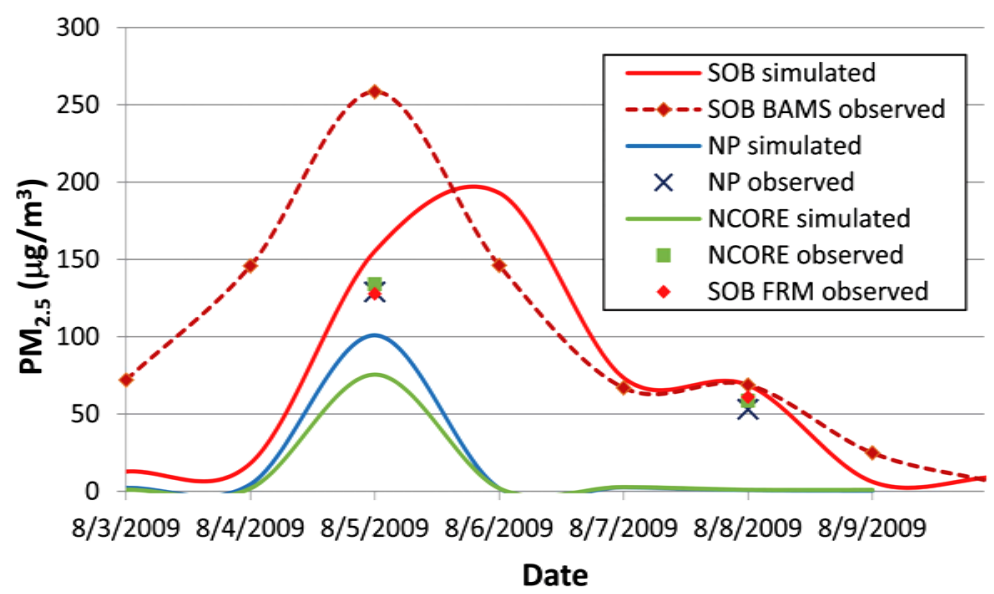

Figure 3. Temporal evolution of hourly $\mathrm{PM}_{2.5}$ concentrations as simulated (solid lines) and observed (markers) at the State Office building in downtown Fairbanks (SOB) with the BAMS and FRM instruments, in the city of North Pole (NP), and at the proposed NCORE site in Fairbanks. North Pole belongs to the Fairbanks metropolitan area and is located about $21 \mathrm{~km}$ southeast of Fairbanks. August 3 to 4 were during the spin-up of the chemical fields.

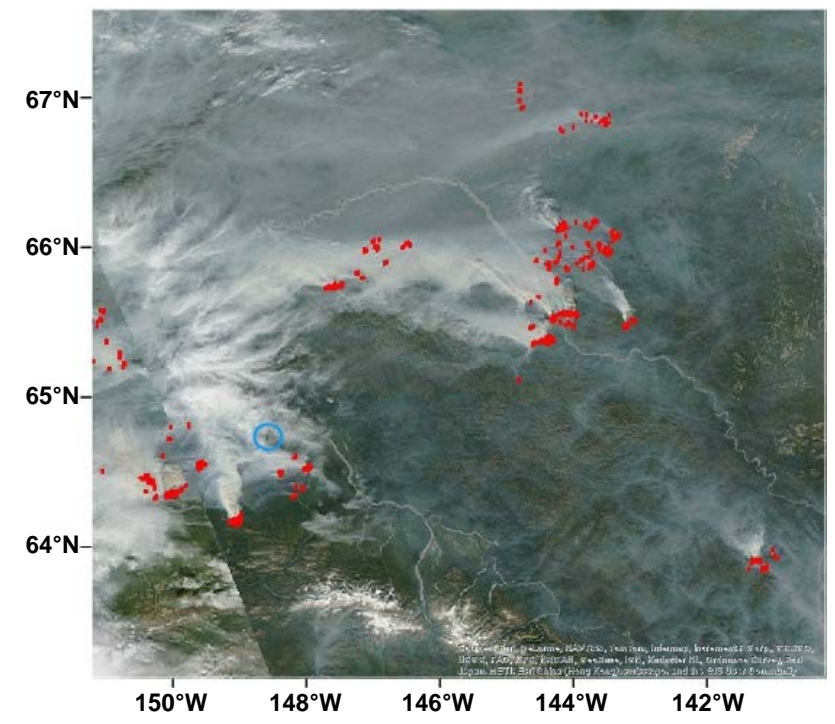

(a)

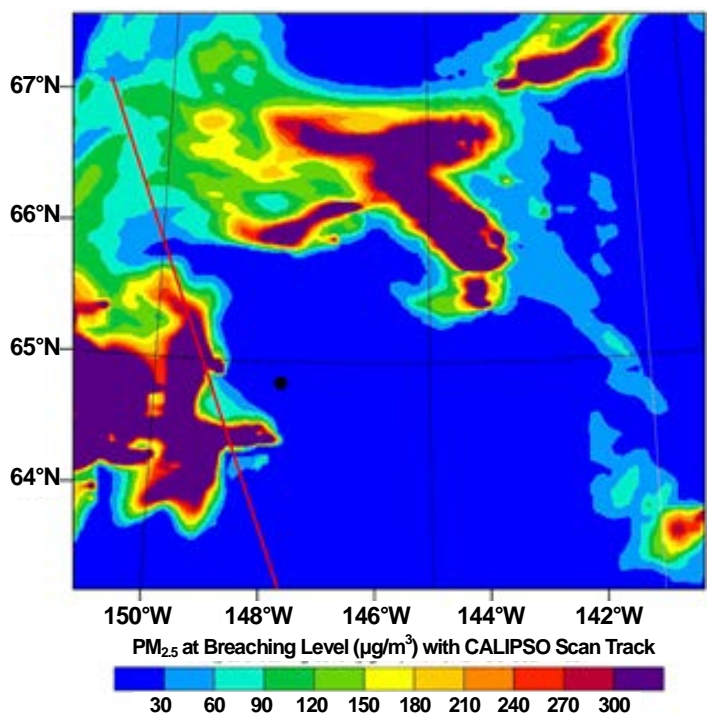

(b)

Figure 4. (a) MODIS visible channel data at the time of the CALIPSO path (red line in part (b)) at 1201 UTC, and (b) WRF/Chem simulated $\mathrm{PM}_{2.5}$ distribution at 1200 on August 5, 2009. The red dots and blue circle in (a) mark the locations of active fires and the AERONET site at Bonanza Creek (30 km southwest of Fairbanks). The black dot in (b) marks the location of Fairbanks.

Comparison of WRF/Chem vertical-integrated horizontal distributions of smoke extend with MODIS data (e.g. Figure 4) suggested similar spatial offsets of the WRF/Chem-simulated smoke plume as found in the comparison with CALIPSO data.

Comparison of simulated and observed cloud distributions revealed that in mountainous terrain, WRF/Chem underestimated convection related to slope winds. This shortcoming was because WRF/Chem used the mean terrain height as representative for the terrain height within each grid-cell. Consequently, steep or small valleys were of subgrid-scale. Furthermore, WRF/Chem had difficulties capturing some of the cirrus seen in MODIS and/or CALIPSO data due to the coarse vertical grid resolution at these heights.

Above high-level clouds and in the upper troposphere, simulated $\mathrm{PM}_{10}$ concentrations showed a homogeneous distribution with marginal changes over time. On the contrary, the CALIPSO data suggested more heterogenous distributions. This discrepancy was due to the coarse resolution of WRF/Chem in the upper troposphere. For the 
same reason, WRF/Chem failed to simulate some of the cirrus clouds and the full vertical extent of high reaching convection (e.g. Figure 5).

\subsection{General Findings Regarding Sampling by UAV}

The virtual sampling focused on the $60 \mathrm{~km} \times 60 \mathrm{~km}$ area centered over the Crazy Mountain fires complex (Figure 1). Following [3] $20 \mathrm{~h}$ mean values determined from virtual sampling were compared to the $20 \mathrm{~h}$ means of the WRF/Chem data that served as the "grand truth" dataset.

The $20 \mathrm{~h}$ mean distributions from sampling at three altitudes were able to capture the vertical gradients for air and dewpoint temperature $\left(\mathrm{O}_{3}\right)$ that naturally increase (decrease) with height in the ABL. These distributions also captured pertubations of these general features when the perturbations occurred due to advection.

After the cold front passed on August 6, concentrations of particulate matter were quasi-uniform at all heights. Thereafter, heterogeneity increased as time progressed.

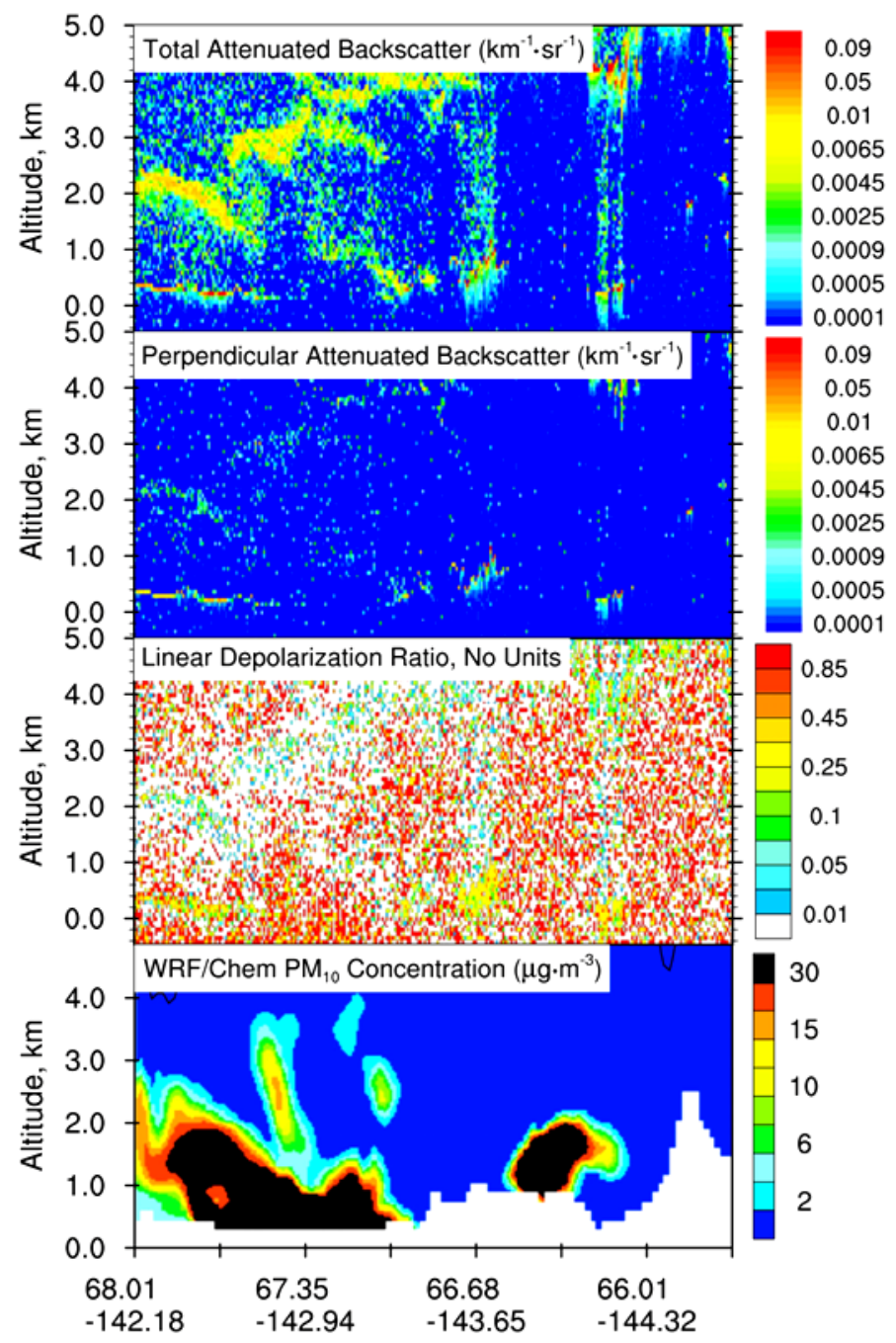

Figure 5. Example of evaluation by CALIPSO data: Nighttime total attenuated backscatter, perpendicular attenuated backscatter, and LDR for the CALIPSO path on August 5, 2009 at 1201 UTC. Note the increase in backscatter from the surface up to $2 \mathrm{~km}$ height. An increase in depolarization is visible at the surface up to $2 \mathrm{~km}$ above ground. These data indicate particulate matter extending from the surface upward. WRF/Chem simulated total liquid and solid mixing ratio distribution (contours) and $\mathrm{PM}_{10}$ concentrations (color shades) at 1200 UTC. 
The following applied to all sampling heights, flight patterns, and flight speeds:

- For all constituents, $20 \mathrm{~h}$ mean concentration distributions differed stronger from the "grand truth" on the day with the frontal passage than on the days prior to or after the event.

- The $20 \mathrm{~h}$ mean distributions from sampling differed strongest among each other and from the "grand truth" for field quantities with a distinct diurnal course.

- The virtual UAV may sample in areas of extreme values. However, the $20 \mathrm{~h}$ means smoothed the distributions due to changes in wind directions and because the magnitudes of minima and maxima varied in time.

- The likelihood for sampling in the region of maximum values decreased as the spatial-temporal varibility in plume location increased.

- Correlation between sampled and "grand truth" means decreased, and errors (e.g. RMSE, NMB, FB) increased with increasing natural spatio-temporal heterogeneity of the field quantity.

\subsection{Temperature and Dewpoint Temperature}

Our discussion focused on an area that a Scan Eagle could cover within $20 \mathrm{~h}$ of sampling (Figure 1). For each day of August 3 to 10, we determined the distribution of $20 \mathrm{~h}$ means from the WRF/Chem data over the sampling domain as the reference of the "grand truth". Sampling at three heights with three different speeds and flight patterns yielded the following.

On average (August 3 to 10 ), temperatures differed about $1^{\circ} \mathrm{C} \cdot 100 \mathrm{~m}^{-1}$ between the three flight levels, i.e. the lower ABL was nearly dry-adiabatic except for August 6, the day of the cold front passage. The virtual sampling reflected this vertical behavior well in all cases.

Typically, distributions derived from sampled temperatures differed the strongest from the "grand truth" where the virtual UAV sampled at times around the daily maximum temperature. Sampled and "grand truth" mean temperatures agreed best on days without frontal activity in the sampling domain. On these days, the design of the flight patterns barely played a role for the differences between sampling-derived and "grand truth" distributions of $20 \mathrm{~h}$ mean temperatures.

Discepancies between sampling-derived and "grand truth" distributions of air temperatures at low altitude exceeded those at high altitude in the ABL (Figure 6). At $200 \mathrm{~m}$, surface heterogeneity still affected vertical motions and sensible heat flux densities that documented themselves in notable horizontal variations of temperature. At the top of the ABL, however, the fluxes blended to a relative homogeneous distribution. The diurnal temperature course vanished at this height. Note that RMSEs and SDEs from heterogenous samples are naturally larger than from comparatively more homogeneous samples [64].

On days without any changes in the synoptic conditions, mean differences between the temperature distributions obtained for the three flight patterns and the "grand truth" were less than $2^{\circ} \mathrm{C}$. However, local differences reached up to $7^{\circ} \mathrm{C}$. Typically, at the same height, sampled distributions of air temperatures differed least among each other in the middle, and largest along the boundaries of the sampling domain (Figure 6). This behavior was because the virtual UAV sampled the middle part of the sampling domain at about the same time, but the boundaries at quite different times when flying the three different patterns (cf. Figure 1).

On August 6, the passage of a cold front led to huge discrepancies between sampling-derived distributions in areas affected by the front during the $20 \mathrm{~h}$. Since the cold front sloped backward with height, notable discrepancies occurred over a smaller region at $1000 \mathrm{~m}$ height than at $500 \mathrm{~m}$ or $200 \mathrm{~m}$ (Figure 6). Investigation showed that during frontal events, traveling north-south or vice versa with only $4 \mathrm{~km}$ legs for turning yielded distributions of mean temperatures with $15 \%$ positive (sampled vs. "grand truth") normalized mean biases and fractional mean biases in regions where the front moved in. Long west-east/east-west sampling legs after the passing of the cold front led to significant (p-value $<0.0001)$ negative NMB $(-34 \%)$ and FB $(-28 \%)$. The default sampling pattern, however, yielded an acceptable mean distribution as the positive and negative biases from sampling prior to and after the frontal passage cancelled each other out.

The results from the default and third sampling patterns only slightly differed as both sampled the front at similar times in about the same location. Areas of small and large differences were rotated among the default and third patterns reflecting the relationship of the two sampling patterns (Figure 1, Figure 6). However, the second sampling pattern sampled the moving cold front at a quite different time and location than the default and third patterns. Thus, the distribution of $20 \mathrm{~h}$ mean temperatures obtained from sampling showed considerable differences from the "grand truth." Based on this finding, one has to conclude that under conditions of frontal activity, 


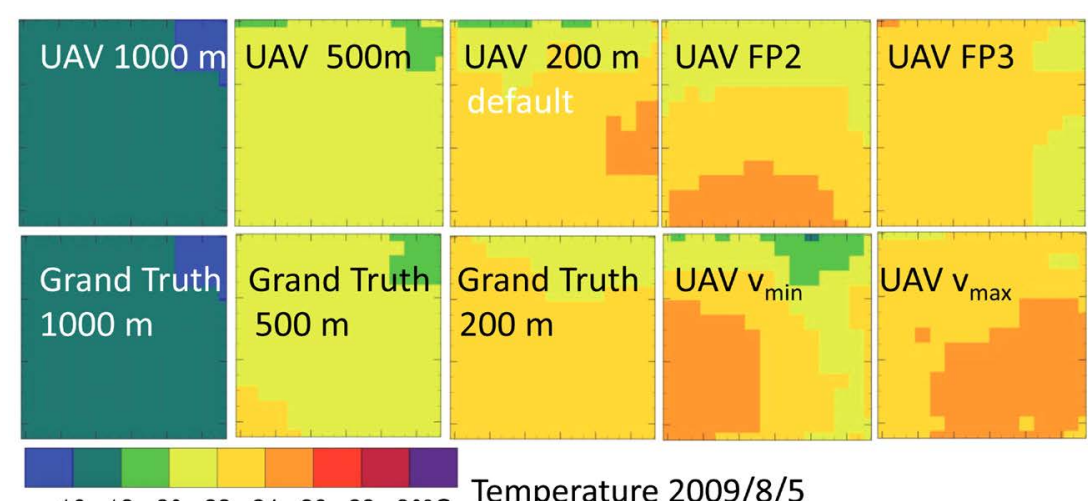

$\begin{array}{llllllll}16 & 18 & 20 & 22 & 24 & 26 & 28 & 30^{\circ} \mathrm{C} \text { Temperature } 2009 / 8 / 5\end{array}$

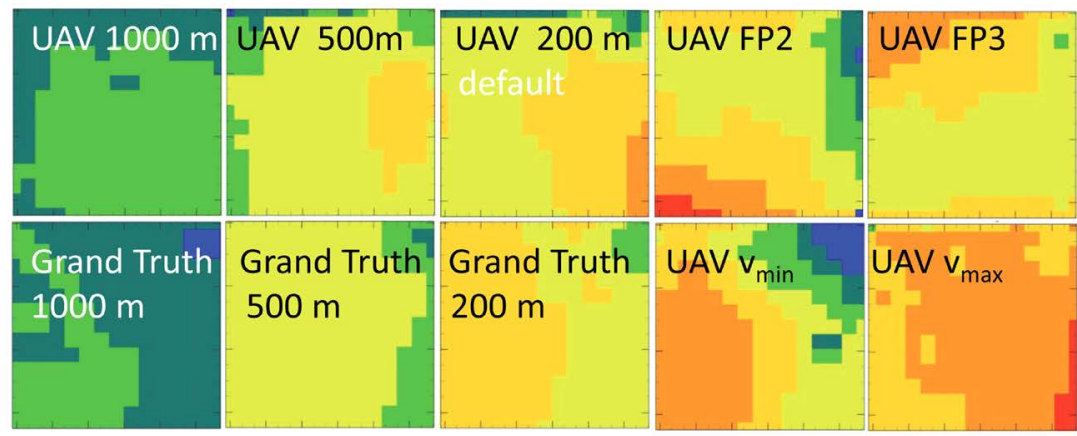

$\begin{array}{llllllll}16 & 18 & 20 & 22 & 24 & 26 & 28 & 30^{\circ} \mathrm{C}\end{array}$ Temperature 2009/8/6
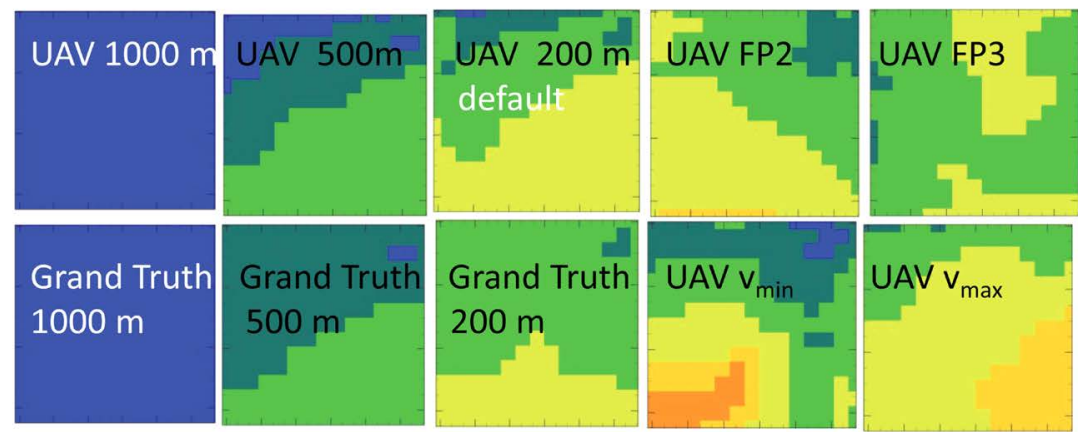

$\begin{array}{llllllll}16 & 18 & 20 & 22 & 24 & 26 & 28 & 30^{\circ} \mathrm{C}\end{array}$

Temperature 2009/8/7

Figure 6. Distributions of mean temperatures as obtained (top left to bottom right) from virtual sampling at $1000 \mathrm{~m}, 500 \mathrm{~m}, 200 \mathrm{~m}$ (default), flight pattern 2 (FP2) at 200 m, flight pattern 3 (FP3) at $200 \mathrm{~m}$, from the "grand truth" at $1000 \mathrm{~m}, 500 \mathrm{~m}$, and 200 $\mathrm{m}$, from sampling at stall speed $\left(\mathrm{v}_{\min }\right)$ at $200 \mathrm{~m}$, and maximum speed $\left(\mathrm{v}_{\max }\right)$ at $200 \mathrm{~m}$ for prefrontal conditions on August 5 (first two rows of panel), conditions during the frontal passage on August 6 (middle two rows of panel), and after the front passed on August 7 (last two rows of panel). Panels show $20 \mathrm{~h}$ means for all sampling designs except for those using stall and maximum speed.

flight patterns can affect the mean distributions derived therefrom. Consequently, one has to choose the sampling pattern that is most suitable for the research question/task for which the data are needed. This means, applying a virtual sampling using the forecast data can be of help in the flight planning and decision-making process.

According to the "grand truth", episode-mean temperatures over the sampling domain were $20^{\circ} \mathrm{C} \pm 2.6^{\circ} \mathrm{C}$, $19.7^{\circ} \mathrm{C} \pm 2.7^{\circ} \mathrm{C}$, and $13.9^{\circ} \mathrm{C} \pm 2.5^{\circ} \mathrm{C}$ at $200 \mathrm{~m}, 500 \mathrm{~m}$ and $1000 \mathrm{~m}$ height, respectively. On this spatio-temporal mean, the best agreement between sampling-derived and "grand truth" mean temperatures according to the 
RMSE and correlation were flight pattern 2 at cruise-speed, flight pattern 1 at maximum speed, and flight pattern 3 at cruise-speed at $200 \mathrm{~m}, 500 \mathrm{~m}$ and $1000 \mathrm{~m}$ height, respectively. On average over all days of the episode and the sampling domain, RMSE, and SDE were highest $\left(3.2^{\circ} \mathrm{C}-3.5^{\circ} \mathrm{C}, 1.6^{\circ} \mathrm{C}-1.9^{\circ} \mathrm{C}\right)$ at $200 \mathrm{~m}$, and lowest $\left(0.6^{\circ} \mathrm{C}-0.7^{\circ} \mathrm{C}, 0.7^{\circ} \mathrm{C}-0.8^{\circ} \mathrm{C}\right)$ at $1000 \mathrm{~m}$ for all sampling patterns when flying at cruise speed. The mean biases were of the order of measurement accuracy independent of altitude and sampling patterns at cruise speed. Except for the day with the frontal passage, correlations between the distribution of $20 \mathrm{~h}$ mean temperatures from sampling and the "grand truth" were highest at $1000 \mathrm{~m}(0.8-0.9)$ for the various sampling patterns at cruise speed [8].

The investigations on flight speeds suggested that the signature of the diurnal cycle became more obvious in the mean temperature distributions at stall speed than at maximum speed (e.g. Figure 6). During frontal passages, however, the virtual UAV's speed became decisive for whether the sampling occurred predominantly in the region in front of or behind the cold front. The sampled distributions differed from each other for all patterns with largest differences occurring at $200 \mathrm{~m}$.

Looking at the various flight patterns and cruising speeds revealed that the sampling underestimated the mean temperatures on average over all days and the sampling domain by $0.9^{\circ} \mathrm{C}-2.6^{\circ} \mathrm{C}$, and $1.5^{\circ} \mathrm{C}-2^{\circ} \mathrm{C}$ at $200 \mathrm{~m}$ and $500 \mathrm{~m}$ height, respectively, but overestimated it up to $0.4^{\circ} \mathrm{C}$ at $1000 \mathrm{~m}$ height. The sampling suggested about twice as high spatial variation at all altitudes than was present in the "grand truth." Overall, the above findings suggested that determining area-temporal mean values for an area of $60 \mathrm{~km} \times 60 \mathrm{~km}$, about the size of highresolution climate models, provided similar uncertainty than deriving them for small areas, i.e. in our case $4 \mathrm{~km}$ $\times 4 \mathrm{~km}$ areas. However, providing area means for large areas (e.g. the entire Interior Alaska) would require flying several UAVs in adjacent areas at the same time.

In Interior Alaska summer, moist flux densities are not large, for which dewpoint temperatures do not change quickly except when a front moves in. Dewpoint temperatures showed little diurnal variability in the sampled values and the "grand truth" (therefore not shown).

In the U.S. standard atmosphere, dewpoint temperature decreases at a rate of $0.172{ }^{\circ} \mathrm{C} \cdot 100 \mathrm{~m}^{-1}$ [65]. Consequently, distributions of mean dewpoint temperatures sampled at different altitudes have to differ [8]. Wind shear and advection changed the dewpoint-temperature profiles. Thus, dewpoint temperatures decreased at nonconstant rate with height. Consequently, dewpoint-temperature distributions from virtual sampling at different heights differed from each other between $1^{\circ} \mathrm{C}$ and $3^{\circ} \mathrm{C}$. The latter occurred on August 5 due to the approaching low-pressure system.

On average over the episode and sampling domain, "grand truth" dewpoint temperatures were $1^{\circ} \mathrm{C} \pm 0.3^{\circ} \mathrm{C}$, $0.5^{\circ} \mathrm{C} \pm 1.5^{\circ} \mathrm{C}$, and $-0.3^{\circ} \mathrm{C} \pm 1.6^{\circ} \mathrm{C}$ at $200 \mathrm{~m}, 500 \mathrm{~m}$, and $1000 \mathrm{~m}$, respectively. Over the episode and sampling domain, spatio-temporal variability obtained from sampling dewpoint temperatures at $200 \mathrm{~m}$ exceeded that of the "grand truth" by threefold for all three sampling patterns. However, the episode sampling domain mean temperature was captured independent of the flight pattern. In contrast to the $200 \mathrm{~m}$ level, sampling well captured the spatio-temporal variability of dewpoint temperatures at $500 \mathrm{~m}$ and $1000 \mathrm{~m}$ height. The virtual UAV's speed had marginal impact on the differences between distributions of mean dewpoint temperatures from sampling and those derived from the "grand truth" except for August 6 when the cold front went through.

On 6 August, sampling at stall speed showed increases in dewpoint temperatures up to $4^{\circ} \mathrm{C}$ in the western part of the sampling domain. At cruise and maximum speeds, most of the virtual sampling occurred in front of the cold front where dewpoint temperatures were still low.

On average over the episode and sampling domain, discrepancies between sampled and "grand truth" temperatures decreased with height. Sampled mean dewpoint temperature distributions and the "grand truth" correlated the least for sampling at stall speed as part of the area was not sampled within the $20 \mathrm{~h}$ flight duration.

\subsection{Inert Gases}

Even though CO is part of a series of chemical reactions that form photochemical smog, its mean atmospheric lifetime is about 60 days [65] [66]. Thus, CO commonly serves as a tracer of wildfire smoke. By adopting this strategy, we took CO as a representative for an inert gas. Of course, WRF/Chem considered reactions of CO along with aldehydes as part of photochemical smog formation (cf. [26]).

During a wildfire, CO concentrations increase downwind of the fire due to transport. The NAAQS for CO is 35 ppm on $1 \mathrm{~h}$ and 9 ppm on 8 h average [14]. In Interior Alaska, typical ambient mean CO concentrations are 
about 3 ppm [8].

For each day of August 5 to 10, we determined the distribution of $20 \mathrm{~h}$ means from the WRF/Chem data over the sampling domain as the reference ("grand truth"). August 3 and 4 were discarded from the analysis to permit the chemical fields to spinup. This procedure was applied for all chemical species and particulate matter as well.

Prior to the frontal passage, locally, CO concentrations exceeded the $8 \mathrm{~h}$ average in the sampling domain [8]. Vertical differences were strongest prior to the frontal passage, as $\mathrm{CO}$ had built up to a smoke plume on the days before. On August 5, for instance, differences of up to $13.18 \mathrm{ppm}$ occurred between $200 \mathrm{~m}$ and $1000 \mathrm{~m}$. On the day of the frontal passage, according to the "grand truth", highest CO concentrations existed in the western part of the sampling domain and the southeastern corner at all three heights (Figure 7). After the frontal passage, CO reached clean air background concentrations. After August 6, CO concentrations built up again as time progressed [8].

In the sampling domain, CO concentrations decreased about 13\% at most between $200 \mathrm{~m}$ and $1000 \mathrm{~m}$ in both the distributions from virtual sampling and the "grand truth" (Figure 7). The $20 \mathrm{~h}$ mean CO concentrations differed between these heights due to the proximity to the wildfire. On average over the episode (August 5-10), absolute differences between the CO concentrations at $200 \mathrm{~m}$ and $1000 \mathrm{~m}$ locally reached $2 \mathrm{ppm}$, i.e. a strong vertical gradient of $\mathrm{CO}$ existed in the ABL due to the wildfire. The virtual sampling well captured that vertical differences in $\mathrm{CO}$ concentrations were least on the day after the frontal passage (not shown).

At $200 \mathrm{~m}$, for the first and second flight patterns, the $20 \mathrm{~h}$ mean CO distributions based on virtual sampling showed larger spatio-temporal variability than the "grand truth". On the contrary, using the third flight pattern underestimated the spatio-temporal variability on average over the period and sampling domain.

At $500 \mathrm{~m}$ height, the second flight pattern suggested twice as high spatio-temporal variability than the "grand truth." The default and third flight patterns showed the same spatio-temporal variability as the "grand truth." This finding differs from that of temperature and dewpoint temperature due to the stronger spatial (horizontal and vertical) heterogeneity of CO. On average over the episode, sampling at $500 \mathrm{~m}$ represented the distribution of relatively higher and relatively lower $\mathrm{CO}$ concentrations the best because the wind field was less turbulent at this height than at $200 \mathrm{~m}$. Compared to CO concentrations at the $200 \mathrm{~m}$ height, the differences between high and low concentrations were smaller at $500 \mathrm{~m}$ height.

Since the height of the ABL varied during the $20 \mathrm{~h}$, virtual sampling at $1000 \mathrm{~m}$ was sometimes above the inversion where concentrations were lower than below the top of the ABL. At $1000 \mathrm{~m}$, all sampling patterns underestimated the spatio-temporal variability by a factor of two. Air-quality models are considered to have high preformance when predicted concentrations agree within a factor of two with the observations [55]-[67]. When

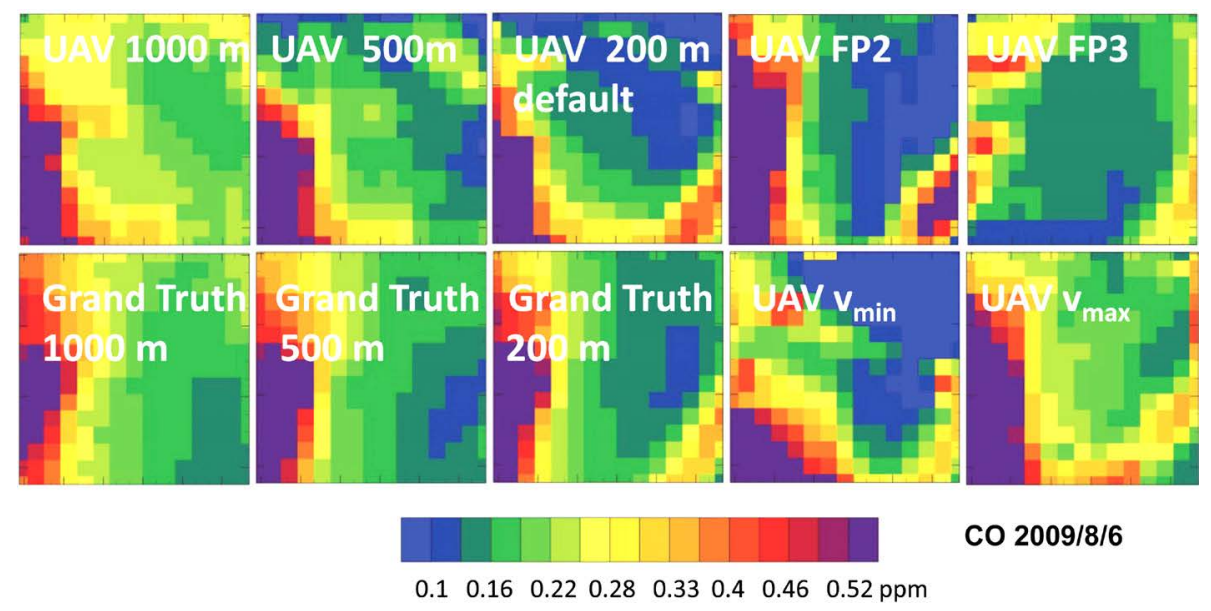

Figure 7. Distributions of mean CO concentrations as obtained (top left to bottom right) from virtual sampling at $1000 \mathrm{~m}, 500 \mathrm{~m}, 200 \mathrm{~m}$ (default), flight pattern 2 (FP2) at $200 \mathrm{~m}$, flight pattern 3 (FP3) at $200 \mathrm{~m}$, from the "grand truth" at $1000 \mathrm{~m}, 500 \mathrm{~m}$, and $200 \mathrm{~m}$, from sampling at stall speed $\left(\mathrm{v}_{\min }\right)$ at $200 \mathrm{~m}$, and maximum speed $\left(\mathrm{v}_{\max }\right)$ at $200 \mathrm{~m}$ during the frontal passage on August 6. Panels show 20 h means for all sampling designs except for those using stall and maximum speed. Note that discrepancies between the distributions from virtual sampling and the "grand truth" on other days look similar (therefore not shown). 
applying the same quality criterion for good agreement to the $20 \mathrm{~h}$ mean CO distributions derived from sampling vs. those of the "grand truth" like in air-quality modeling our findings mean that the calculation of $20 \mathrm{~h}$ mean distributions from UAV data will provide valuable results.

These findings for the sensitivity of derived CO distributions to flight patterns differed from that of temperature and dewpoint temperature. Recall for both air and dewpoint temperatures, the first and third patterns captured the $20 \mathrm{~h}$ mean distributions of the "grand truth" in a similar way. Obviously, which sampling pattern is the most suitable depends on the vertical profiles and horizontal distributions of the sampled quantities. These distributions were quite different for $\mathrm{CO}$ and air temperature/dewpoint temperature.

The injection height for all wildfire-released species was calculated inline by WRF/Chem. Injection height varied with time reaching up to $4 \mathrm{~km}$ above ground level at some times. This means species and temperature distributions were not collocated in space and time.

These differences in the distributions of the sampled quantities suggest that a numerical forecast and virtual sampling of the forecasted quantities may be needed to decide on flight levels and sampling patterns for the various quantities to be observed by a cohort of UAVs. In other words, our findings mean that different flight patterns are to be considered for UAVs depending on the mounted instrument.

\subsection{Reactive Primary Pollutants}

Among other things, wildfires release $\mathrm{SO}_{2}$ and $\mathrm{NO}$ [22] [66] [68]. These primary pollutants undergo chemical reactions thereby building secondary pollutants. They are also precursor gases for aerosol formation [66]. In Interior Alaska, annual mean near-surface $\mathrm{SO}_{2}$ concentrations are about $35 \mathrm{ppb}$ [8]. The NAAQS for $\mathrm{SO}_{2}$ for $1 \mathrm{~h}$ and $3 \mathrm{~h}$ are $75 \mathrm{ppb}$ and $0.5 \mathrm{ppm}$, respectively [14]. The latter is not to be exceeded more than once per year.

Prior to the frontal passage, $20 \mathrm{~h}$ mean $\mathrm{SO}_{2}$ concentrations ranged between $2 \mathrm{ppb}$ outside the plume and 18 $\mathrm{ppb}$ in the plume at $200 \mathrm{~m}$ (Figure 8). The relatively low $20 \mathrm{~h} \mathrm{SO}_{2}$ concentration means resulted from the plume's meandering due to the calm winds. At $500 \mathrm{~m}, 20 \mathrm{~h}$ mean maximum concentrations exceeded $4 \mathrm{ppb}$. Local inversions hindered vertical exchange in some areas of the sampling domain. Thus, at $1000 \mathrm{~m}, 20 \mathrm{~h}$ mean $\mathrm{SO}_{2}$ concentrations were elevated or represented clean air background concentrations. Immediately after the frontal passage, $20 \mathrm{~h}$ mean $\mathrm{SO}_{2}$ concentrations corresponded to clean air background values at all three heights $(<1 \mathrm{ppb})$. On the day after the frontal passage, highest $\mathrm{SO}_{2}$ concentrations occurred in the western part of the sampling domain at $1000 \mathrm{~m}$ height building up over time due to advection of wildfire smoke. Due to the weak winds peaks in $\mathrm{SO}_{2}$ concentrations occurred in similar locations at the three altitudes with slightly higher concentrations at increasing altitude.

The $20 \mathrm{~h}$ mean distributions of $\mathrm{SO}_{2}$ constructed from sampling showed locally positive and negative biases as compared to the "grand truth." Investigations showed that $\mathrm{SO}_{2}$ concentrations decreased at onset of twilight ( 0004 Alaska Daylight Time (AKDT = UTC -8 h)) hinting at photolytic reactions being involved. During the episode of this study, sunrise occurred between 0430 and 0500 AKDT and sunset was between 2300 and 2230 AKDT. The decrease in $\mathrm{SO}_{2}$ and sulfate particulate matter showed no correlation [8]. Thus, gaseous $\mathrm{SO}_{2}$ forming solid aerosols can be excluded as cause of the decrease.

The virtual UAV collected data for $20 \mathrm{~h}$. Hence, it took samples at different times of the diurnal course of $\mathrm{SO}_{2}$ concentrations. In areas where the virtual UAV sampled when concentrations were low in the diurnal course, the $20 \mathrm{~h}$ means derived therefrom underestimated the "grand truth" $20 \mathrm{~h}$ mean $\mathrm{SO}_{2}$ concentrations (cf. Figure 1, Figure 8). The opposite was true for areas where sampling occurred only when concentrations were at their highest in the diurnal course. Consequently, the different sampling patterns yielded different answers for the distributions of $20 \mathrm{~h}$ mean $\mathrm{SO}_{2}$ concentrations.

The cold front reset the $\mathrm{SO}_{2}$ concentrations to clean air background concentrations. Thus, on August 7, the distributions of $20 \mathrm{~h}$ mean $\mathrm{SO}_{2}$ concentrations from sampling and the "grand truth" agreed well independent of the flight patterns in most of the sampling domain except for its southeast corner (Figure 8). During this time, a northwest wind pushed the smoke plume from the wildfire into this area. Differences were due to the time of sampling in this area of the redeveloping smoke plume.

On August 8, wind direction shifted, for which the highest $\mathrm{SO}_{2}$ concentrations occurred farther north and in the center of the sampling domain (not shown). Due to the calming of the winds, the plume dispersed more strongly than the day before. Nevertheless, on all days, the largest differences between the distribution of $20 \mathrm{~h}$ means from $\mathrm{SO}_{2}$ sampling and the $20 \mathrm{~h}$ "grand truth" means occurred along the corners of the sampling domain for all 

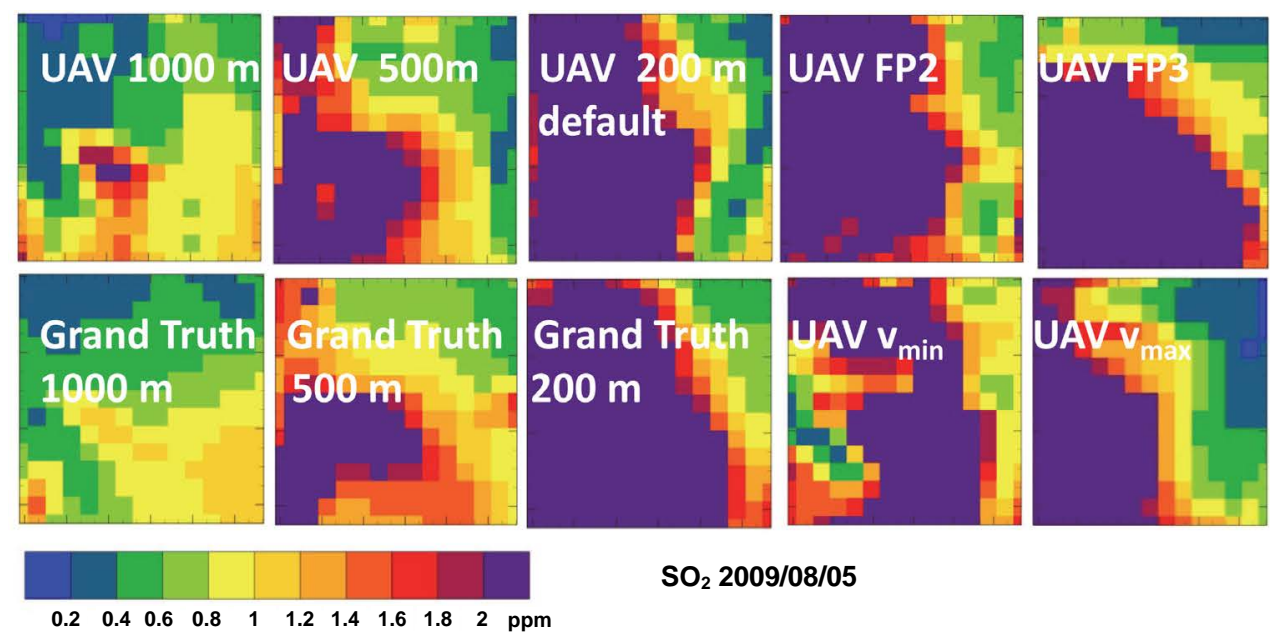

$\mathrm{SO}_{2} 2009 / 08 / 05$

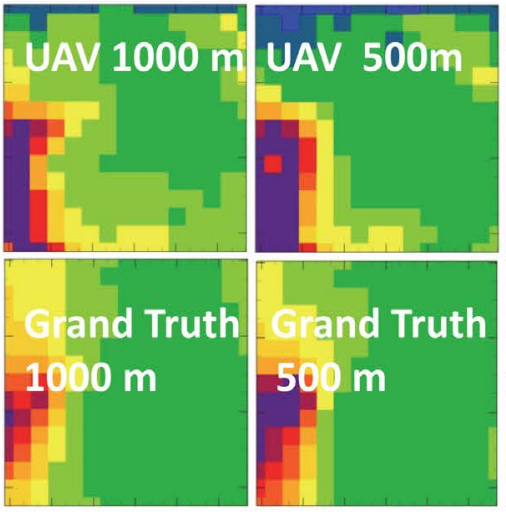

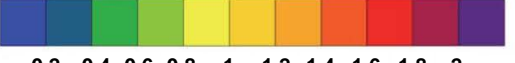

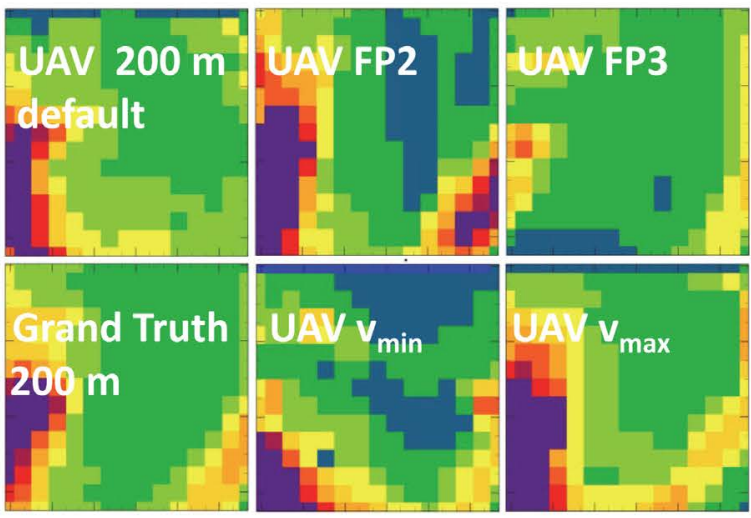

$\mathrm{SO}_{2} 2009 / 08 / 06$

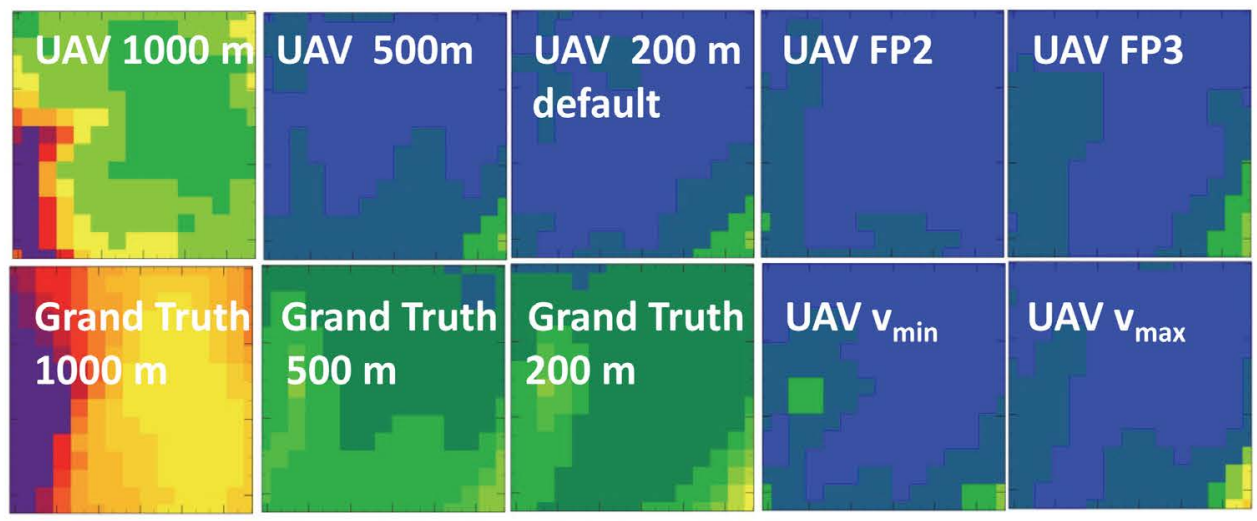

$\mathrm{SO}_{2} 2009 / 08 / 07$

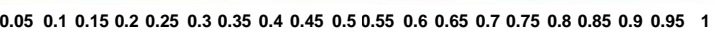

\section{ppm}

Figure 8. Distributions of mean $\mathrm{SO}_{2}$ concentrations as obtained (top left to bottom right) from virtual sampling at $1000 \mathrm{~m}, 500 \mathrm{~m}, 200 \mathrm{~m}$ (default), flight pattern 2 (FP2) at $200 \mathrm{~m}$, flight pattern 3 (FP3) at $200 \mathrm{~m}$, from the "grand truth" at $1000 \mathrm{~m}, 500 \mathrm{~m}$, and $200 \mathrm{~m}$, from sampling at stall speed $\left(\mathrm{v}_{\mathrm{min}}\right)$ at 200 $\mathrm{m}$, and maximum speed $\left(\mathrm{v}_{\max }\right)$ at $200 \mathrm{~m}$ for prefrontal conditions on August 5 (first two rows of panel), conditions during the frontal passage on August 6 (middle two rows of panel) and after the front passed on August 7 (last two rows of panel). Panels show $20 \mathrm{~h}$ means for all sampling designs except for those using stall and maximum speed. Legend for August 7 differs from those of August 5 and 6. 
flight patterns (e.g. Figure 8). Here, data were sampled either within very short time or at long time apart. Thus, one may conclude that both short and long temporal increments between sampling can cause strong biases from the $20 \mathrm{~h}$ means of the "grand truth" for species that have a notable diurnal course (cf. Sections 3.1, 3.3, Figure 1).

Typically, independent of the virtual UAV's speed, $20 \mathrm{~h}$ mean $\mathrm{SO}_{2}$ concentrations were overestimated and underestimated within areas of high and low concentrations, respectively (e.g. Figure 8). The 20 h mean $\mathrm{SO}_{2}$ concentrations derived from virtual sampling at different speeds roughly agreed with each other and the "grand truth.” However, at stall speed, differences throughout the sampling domain were larger and less localized than at cruising or maximum speeds. When sampled at maximum speed, $20 \mathrm{~h}$ mean $\mathrm{SO}_{2}$ concentrations from sampling correlated the strongest with those of the "grand truth" (0.7 at $200 \mathrm{~m}, 0.9$ at both $500 \mathrm{~m}$ and $1000 \mathrm{~m})$.

However, at $200 \mathrm{~m}$ altitude, $20 \mathrm{~h} \mathrm{SO}_{2}$ concentration means from sampling captured the spatio-temporal variability best when flying at stall speed. Flying at maximum speed suggested 50\% higher spatio-temporal variability than existed according to the "grand truth" at $200 \mathrm{~m}$. On average, at $500 \mathrm{~m}$ altitude, spatio-temporal variability was underestimated at all speeds by $44 \%$ to $77 \%$. The strongest (least) underestimation occurred at cruising (stall) speed. At $1000 \mathrm{~m}$, on average, the largest underestimation of spatio-temporal variability occurred at stall speed, while flying at maximum speed provided the best results and highest correlation of sampled and "grand truth" 20 h mean $\mathrm{SO}_{2}$ concentrations. Based on these findings, one has to conclude that sampling $\mathrm{SO}_{2}$ concentrations at high speeds minimizes errors. This finding is because the virtual UAV needs less time to cover the entire sampling domain. Thus, signals of extremes in the diurnal course have less impact at highest than at slower speeds.

Due to the sparse population and synoptic situation, the main source of NO in the sampling domain was the Crazy Mountain fires. Due to the reactivity of NO, the NAAQS considers $\mathrm{NO}_{2}$ with a $1 \mathrm{~h}$ average of 100 ppb [14].

Like for $\mathrm{SO}_{2}$, NO has a diurnal cycle due to photochemical reactions [66]. The analysis of the results for NO confirmed those of $\mathrm{SO}_{2}$. Concentrations were overestimated (underestimated) in areas of high (low) NO concentrations (Figure 9). Like for $\mathrm{SO}_{2}$, $\mathrm{NO}$ concentrations reset to clean air background values when the cold front passed the sampling domain, and the smoke plume re-developed after the front had passed.

On episode (August 5 to 10) and sampling domain average, sampled and "grand truth" NO concentrations agreed best with respect to the combined RMSE and correlations scores for flight pattern 1 at maximum cruise speed at all heights.

In summary, the virtual sampling showed that due to the diurnal cycle of pollutants involved in photochemistry 20 h mean distributions locally fail to capture the 20 h mean of the "grand truth" undoubtly. For all days after spinup, i.e. also on the days without frontal passage, the obtained distributions were sensitive to when the UAV passed an area. Analysis suggested that data should be separated for daylight and dark hours to determine daylight and nighttime mean distributions instead of $20 \mathrm{~h}$ mean distributions [8].

\subsection{Secondary Pollutants}

Secondary pollutants like $\mathrm{O}_{3}$ form by reactions involving primary pollutants. The NAAQS for $\mathrm{O}_{3}$ is an $8 \mathrm{~h}$ average concentration of $75 \mathrm{ppb}$ [14]. In Interior Alaska, typical $\mathrm{O}_{3}$ concentrations are about $40 \mathrm{ppb}$ [8].

Recall that during the episode of our study, complete darkness occurred only for about 4 to 5 hours. According to the $\mathrm{WRF} / \mathrm{Chem}$ data, $\mathrm{O}_{3}$ concentrations showed no distinct minimum during daylight despite the reactions with NO and VOCs. The distributions of 20 h mean $\mathrm{O}_{3}$ concentrations showed an increase of $\mathrm{O}_{3}$ with increasing height. Typically, $20 \mathrm{~h}$ mean $\mathrm{O}_{3}$ concentrations ranged between 36 and $44 \mathrm{ppb}, 40$ and 50 ppb, and 42 and 52 ppb at $200 \mathrm{~m}, 500 \mathrm{~m}$ and $1000 \mathrm{~m}$ height, respectively. Overall, the $\mathrm{O}_{3}$ distributions showed low spatial features at the three heights and on all days. Comparison of the $\mathrm{O}_{3}$ concentrations prior to and after the cold front indicated some ozone formation due to the wildfire emissions.

The low spatial and temporal changes in $\mathrm{O}_{3}$ concentrations yielded for the default and second flight patterns provided broadly similar distributions of $20 \mathrm{~h}$ means (Figure 10). However, these distributions failed to capture that of the "grand truth." The third flight pattern captured the location of relatively high and low concentrations best. Nevertheless, discrepancies between 20 h means from virtual sampling and the "grand truth" were about \pm 4 ppb for all three flight patterns.

Obviously, sampling of $\mathrm{O}_{3}$ concentrations is sensitive to the UAV's speed (cf. Figure 10). Typically, $20 \mathrm{~h}$ mean $\mathrm{O}_{3}$ concentrations were higher for flying at stall or maximum speed as compared to flying at cruising speed. Distributions of $20 \mathrm{~h}$ mean $\mathrm{O}_{3}$ concentrations agreed best with those of the "grand truth" when the virtual 

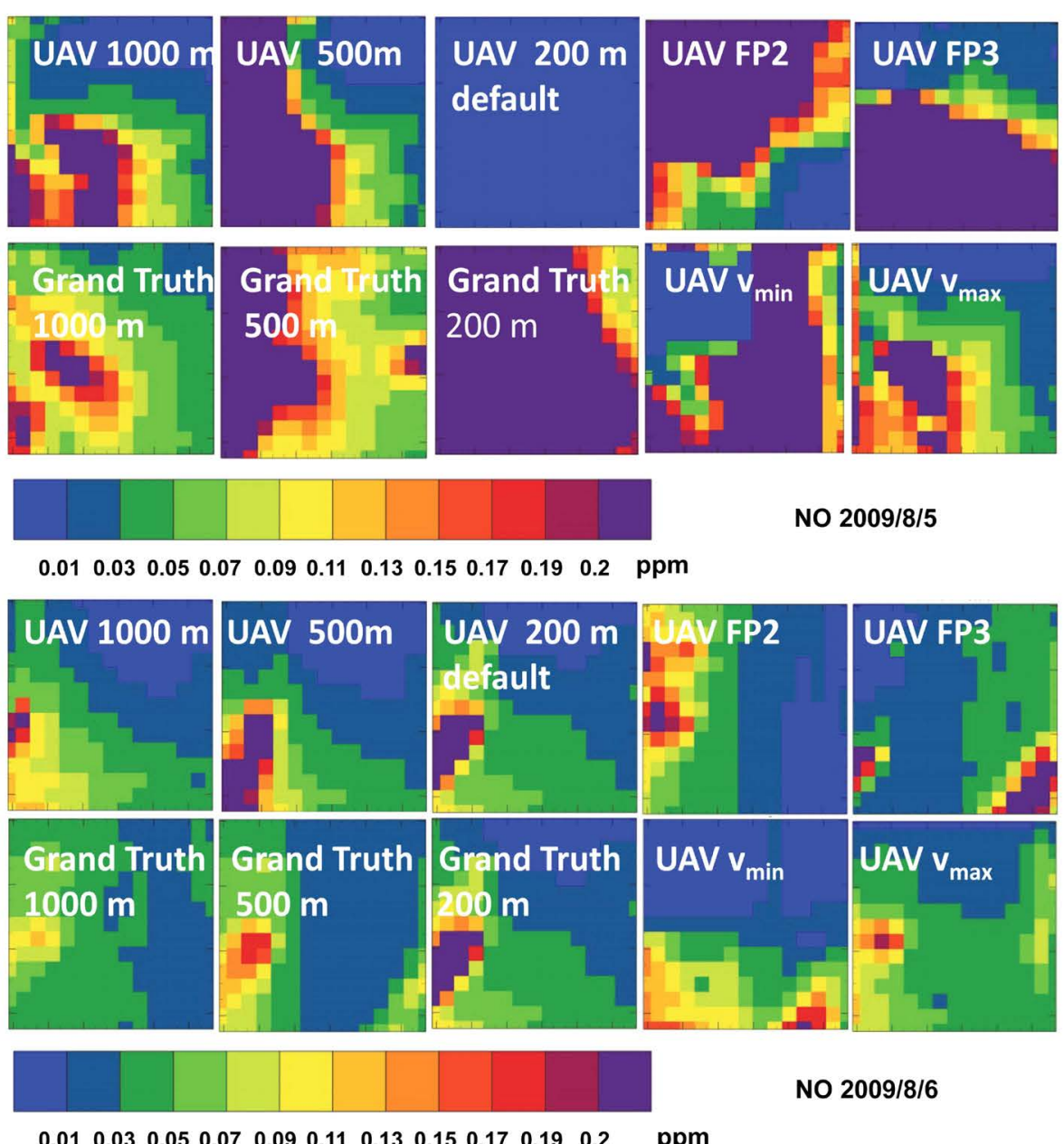

NO 2009/8/6

$\begin{array}{llllllllllll}0.01 & 0.03 & 0.05 & 0.07 & 0.09 & 0.11 & 0.13 & 0.15 & 0.17 & 0.19 & 0.2 & \mathrm{ppm}\end{array}$
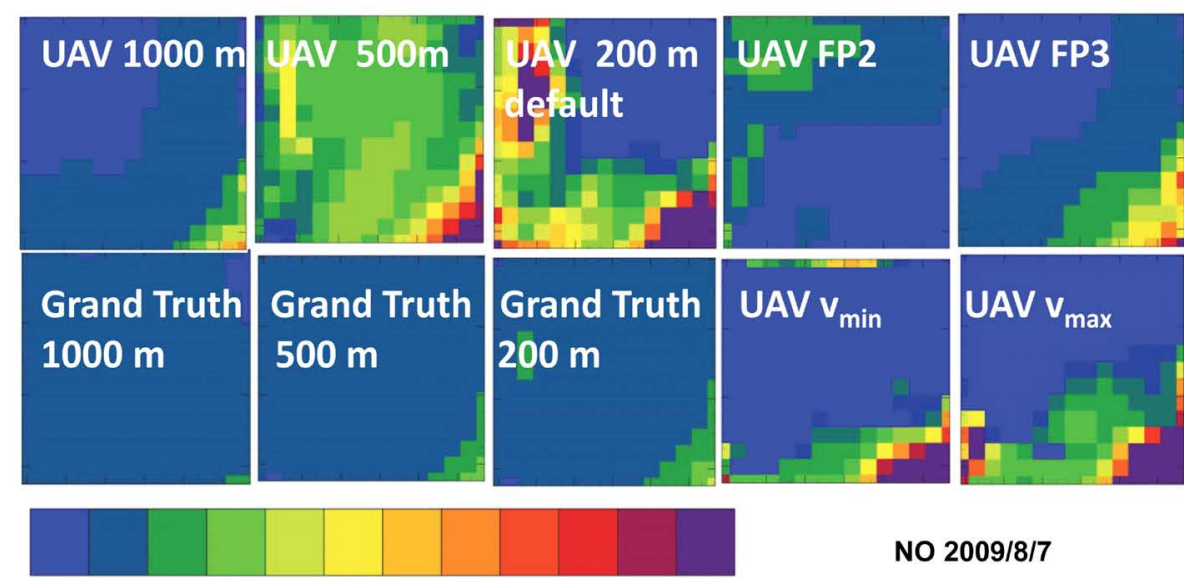

NO $2009 / 8 / 7$

$\begin{array}{llllllllllll}0.01 & 0.03 & 0.05 & 0.07 & 0.09 & 0.11 & 0.13 & 0.15 & 0.17 & 0.19 & 0.2 & \mathrm{ppm}\end{array}$

Figure 9. Distributions of mean NO concentrations as obtained (top left to bottom right) from virtual sampling at $1000 \mathrm{~m}, 500 \mathrm{~m}, 200 \mathrm{~m}$ (default), flight pattern 2 (FP2) at $200 \mathrm{~m}$, flight pattern 3 (FP3) at $200 \mathrm{~m}$, from the "grand truth" at $1000 \mathrm{~m}, 500 \mathrm{~m}$, and $200 \mathrm{~m}$, from sampling at stall speed $\left(\mathrm{v}_{\min }\right)$ at $200 \mathrm{~m}$, and maximum speed $\left(\mathrm{v}_{\max }\right)$ at $200 \mathrm{~m}$ for prefrontal conditions on August 5 (first two rows of panel), conditions during the frontal passage on August 6 (middle two rows of panel) and after the front passed on August 7 (last two rows of panel). Panels show $20 \mathrm{~h}$ means for all sampling designs except for those using stall and maximum speed. 

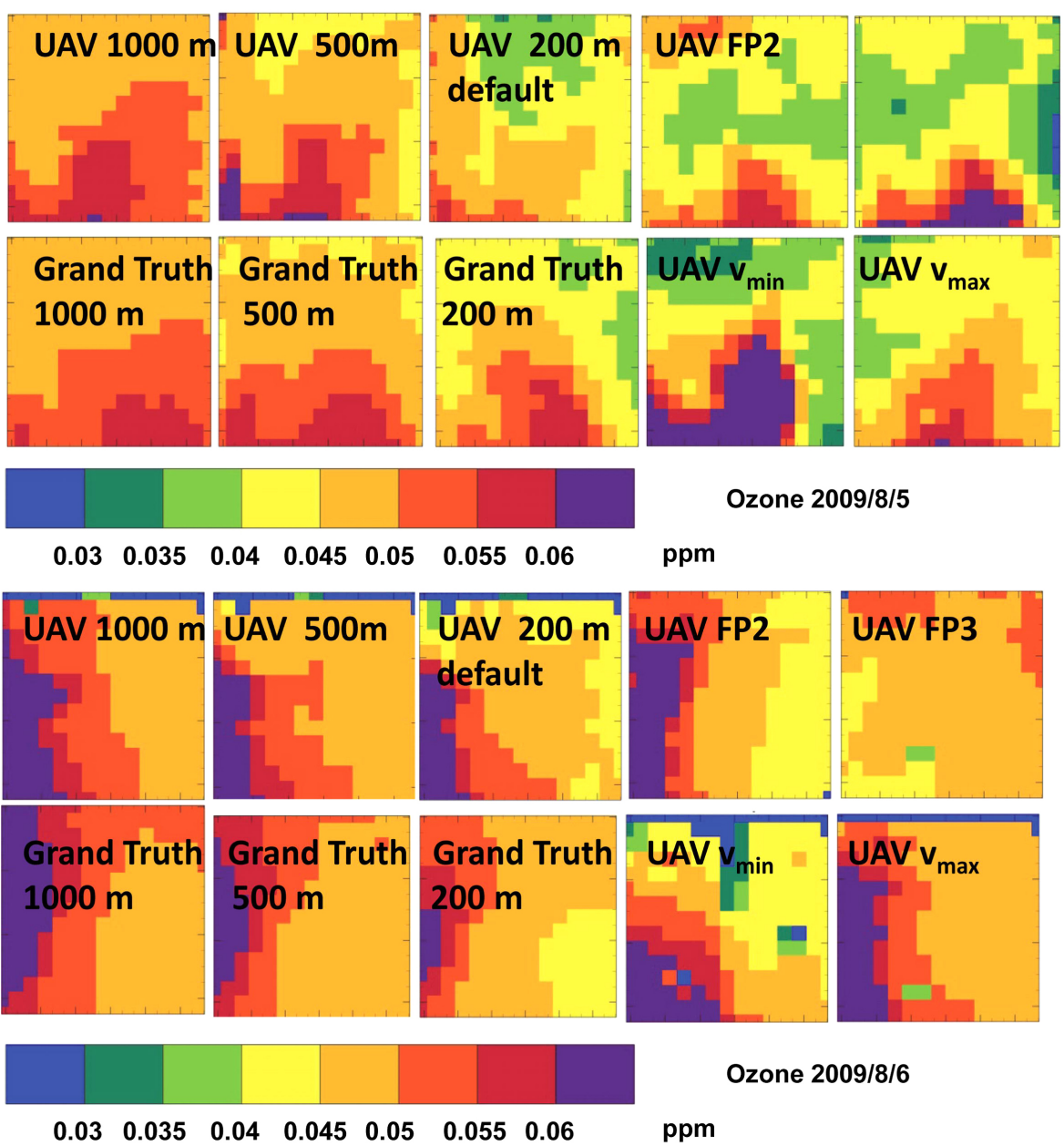

Ozone 2009/8/6

$\begin{array}{lllllll}0.03 & 0.035 & 0.04 & 0.045 & 0.05 & 0.055 & 0.06\end{array}$

ppm
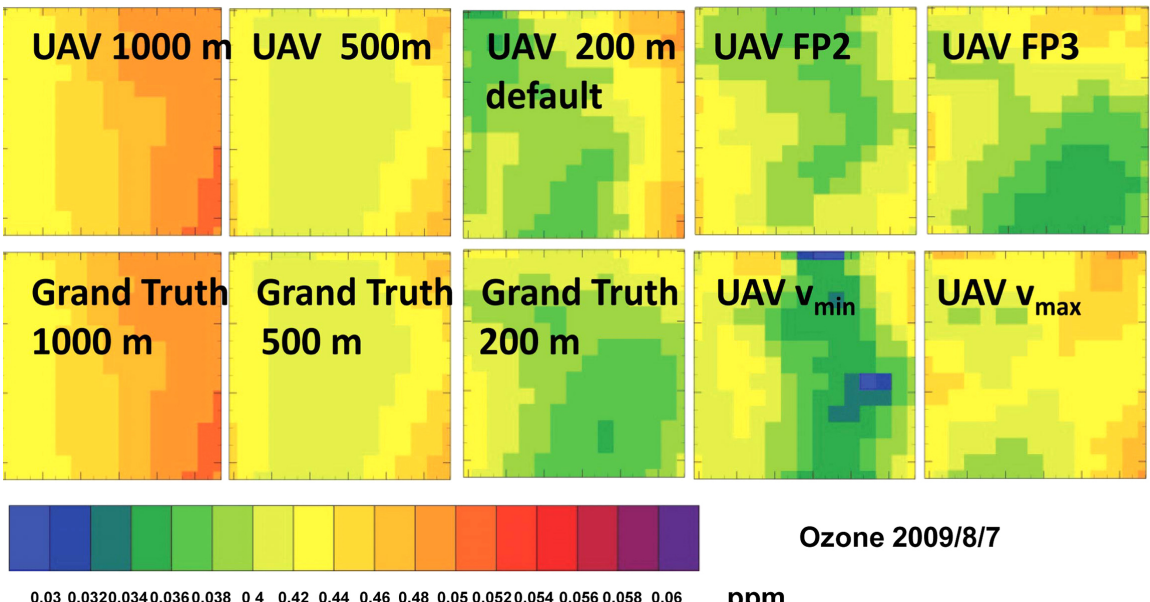

Ozone 2009/8/7

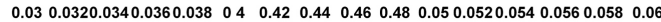

ppm

Figure 10. Distributions of mean $\mathrm{O}_{3}$ concentrations as obtained (top left to bottom right) from virtual sampling at $1000 \mathrm{~m}, 500 \mathrm{~m}, 200 \mathrm{~m}$ (default), flight pattern 2 (FP2) at $200 \mathrm{~m}$, flight pattern 3 (FP3) at $200 \mathrm{~m}$, from the "grand truth" at $1000 \mathrm{~m}, 500 \mathrm{~m}$, and $200 \mathrm{~m}$, from sampling at stall speed $\left(\mathrm{v}_{\min }\right)$ at $200 \mathrm{~m}$, and maximum speed $\left(\mathrm{v}_{\max }\right)$ at $200 \mathrm{~m}$ for prefrontal conditions on August 5 (first two rows of panel), conditions during the frontal passage on August 6 (middle two rows of panel) and after the front passed on August 7 (last two rows of panel). Panels show $20 \mathrm{~h}$ means for all sampling designs except for those using stall and maximum speed. Legend for August 7 differs from those for August 5 and 6. 
UAV flew at cruise speed. Since the obtained $20 \mathrm{~h}$ mean $\mathrm{O}_{3}$ distributions were best at cruise speed, an optimum sampling speed may exist that could be determined by virtual sampling.

\subsection{Particulate Matter}

Particulate matter (PM) can form in the atmosphere from precursor gases by gas-to-particle conversion [16] [66]. The wildfires were the main source for particulate matter in this area of the model domain. Currently, the NAAQS for $24 \mathrm{~h}$ mean $\mathrm{PM}_{10}$ and $\mathrm{PM}_{2.5}$ are 150 and $35 \mu \mathrm{g} \cdot \mathrm{m}^{-3}$, respectively [14]. Except for the Fairbanks metropolitan area and in the downwind of wildfires, typical concentrations are below $2 \mu \mathrm{g} \cdot \mathrm{m}^{-3}$ [29].

According to the "grand truth" during the episode, $20 \mathrm{~h}$ mean $\mathrm{PM}_{10}$ concentrations were highest at the $200 \mathrm{~m}$ flight level except for August 6 (Figure 11). Then $20 \mathrm{~h}$ mean $\mathrm{PM}_{10}$ concentrations reached up to $71.9 \mu \mathrm{g} \cdot \mathrm{m}^{-3}$ and $6.23 \mu \mathrm{g} \cdot \mathrm{m}^{-3}$ at $1000 \mathrm{~m}$ and $200 \mathrm{~m}$, respectively. At the lower flight levels, the UAV sampled in the cold sector. Here precipitation had removed already $\mathrm{PM}_{10}$. At $1000 \mathrm{~m}$, the virtual UAV sampled data in the polluted air of the warm sector.

The obtained $20 \mathrm{~h}$ mean distributions of $\mathrm{PM}_{10}$ concentrations depended much more on the flight patterns than the meteorological or gaseous quantities (cf. Figure 6 to Figure 11), especially during precipitation. On August 6, $20 \mathrm{~h}$ mean distributions derived from sampling with the default and second flight patterns showed greater discrepancies from the "grand truth" than those obtained with the third flight pattern. In the latter case, the virtual UAV followed the precipitation. Consequently, it sampled lower $\mathrm{PM}_{10}$ concentrations than with the default and second flight patterns. Therefore, absolute differences between $20 \mathrm{~h}$ mean $\mathrm{PM}_{10}$ concentrations from sampling and the "grand truth" were smallest for the third flight pattern. The $20 \mathrm{~h}$ mean $\mathrm{PM}_{10}$ distributions obtained by the three flight patterns even differed with respect to the locations of high and low concentrations. In general, distributions from sampling and the "grand truth" correlated higher with increasing cruise height, as there the distributions were more homogeneous than at $200 \mathrm{~m}$.

Sampling at maximum speed permitted capturing high concentrations better than sampling at the other speeds (Figure 11). Unlike for different flight patterns, the differences between the $20 \mathrm{~h}$ mean distributions from sampled data and the "grand truth" showed similar spatial structures. This means that sampling underestimated the $20 \mathrm{~h}$ mean $\mathrm{PM}_{10}$ concentrations in the same area independent of flight speed. Speed determined the magnitude of underestimation.

According to the WRF/Chem data, like for $\mathrm{PM}_{10}$, the $20 \mathrm{~h}$ mean horizontal distributions of $\mathrm{PM}_{2.5}$ varied typically the strongest at the $200 \mathrm{~m}$ flight level (Figure 11, Figure 12). The reason was that the sources were at the ground not far from each other and the landscape modified the flow. As the smog-plume ascended, it experienced mixing. At the top of the ABL, pollutants accumulated leading to high concentrations and horizontal variations at a larger scale than at $200 \mathrm{~m}$ height. On average, $\mathrm{PM}_{2.5}$ concentrations increased with increasing height in the ABL. Consequently, at $200 \mathrm{~m}, 20 \mathrm{~h}$ mean minimum $\mathrm{PM}_{2.5}$ concentrations were lower than the minimum $\mathrm{PM}_{2.5}$ concentrations at $500 \mathrm{~m}$ and $1000 \mathrm{~m}$. On August 8, for instance, local maximum differences between the $20 \mathrm{~h}$ mean concentrations at $200 \mathrm{~m}$ and $1000 \mathrm{~m}$ reached up to $9 \mu \mathrm{g} \cdot \mathrm{m}^{-3}$. Only on 5 August, the ABL was well mixed, i.e. $\mathrm{PM}_{2.5}$ concentrations were nearly constant with height. On August 6 and 7, $20 \mathrm{~h}$ mean $\mathrm{PM}_{2.5}$ concentrations were highest at $500 \mathrm{~m}$ due to light rain showers from clouds with their highest ceilings at $250 \mathrm{~m}$. This behavior did not occur for $\mathrm{PM}_{10}$. Analysis suggested that some $\mathrm{PM}_{2.5}$ swelled and converted to $\mathrm{PM}_{10}$.

Overall, the $20 \mathrm{~h}$ mean $\mathrm{PM}_{2.5}$ distributions derived from sampling followed those of $\mathrm{PM}_{10}$ throughout the episode at $200 \mathrm{~m}$ height (Figure 11, Figure 12). Throughout the episode, the greatest differences between the $20 \mathrm{~h}$ means from sampling and the "grand truth" occurred at the $200 \mathrm{~m}$ level. Here the plume had only marginal dispersion in the horizontal direction. With increasing height and time, the plume had expanded yielding more uniform $\mathrm{PM}_{2.5}$ distributions as compared to the same area at $200 \mathrm{~m}$ height. As a result, differences between the distributions from sampling and the "grand truth" were smaller at the higher levels than at $200 \mathrm{~m}$. However, when the plume migrated with time, notable differences occurred along the edges of the plume.

Generally, $20 \mathrm{~h}$ means of $\mathrm{PM}_{2.5}$ from sampling overestimated the $20 \mathrm{~h}$ means of the "grand truth" (Figure 11). The default and second flight patterns typically produced similar $20 \mathrm{~h}$ mean $\mathrm{PM}_{2.5}$ distributions with respect to the locations of highest concentrations. Typically, the second flight pattern suggested (up to $130 \mu \mathrm{g} \cdot \mathrm{m}^{-3}$ ) higher $20 \mathrm{~h}$ means of $\mathrm{PM}_{2.5}$ than the default pattern. However, the minimum location differed for these flight patterns. The default pattern underestimated the $20 \mathrm{~h}$ mean $\mathrm{PM}_{2.5}$ concentrations of the "grand truth" on average by 2 $\mu \mathrm{g} \cdot \mathrm{m}^{-3}$. Analysis suggested that the substantial differences in $20 \mathrm{~h}$ mean $\mathrm{PM}_{2.5}$ distribution were a product of timing of sampling and vertical mixing rather than horizontal transport. 

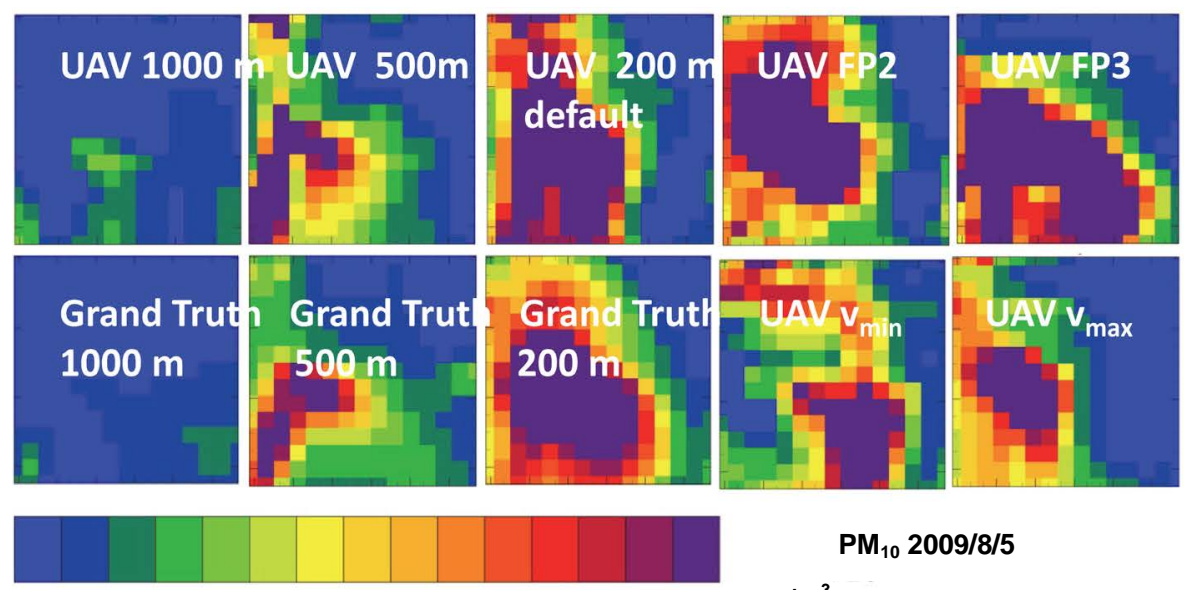

$\mathrm{PM}_{10} 2009 / 8 / 5$

507090110130150170190210230250270290310 $\mu \mathrm{g} / \mathrm{m}^{3}$
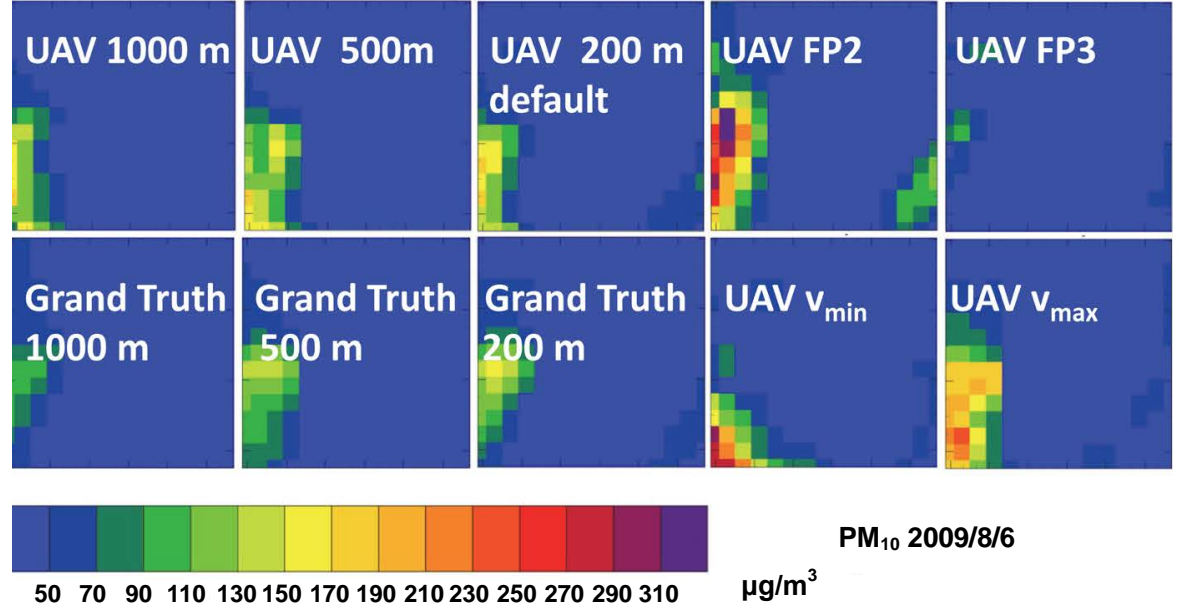

\section{$\mu \mathrm{g} / \mathrm{m}^{3}$}
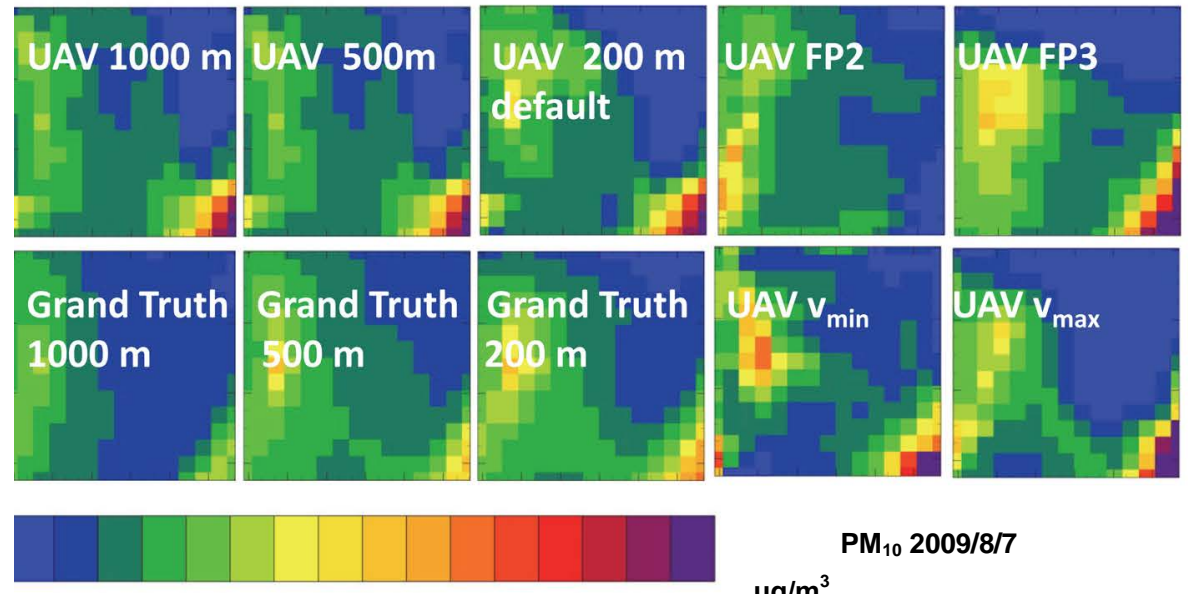

$\begin{array}{lllllllllllllll}2 & 4 & 6 & 8 & 10 & 12 & 14 & 16 & 18 & 20 & 22 & 24 & 26 & 28 & 30\end{array}$
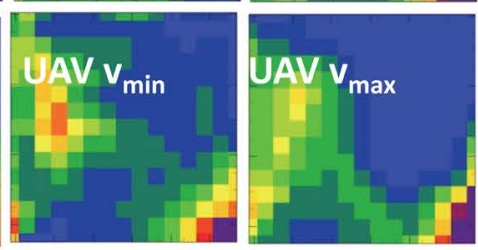

$\mathrm{PM}_{10}$ 2009/8/7

Figure 11. Distributions of mean $\mathrm{PM}_{10}$ concentrations as obtained (top left to bottom right) from virtual sampling at $1000 \mathrm{~m}, 500 \mathrm{~m}, 200 \mathrm{~m}$ (default), flight pattern 2 (FP2) at $200 \mathrm{~m}$, flight pattern 3 (FP3) at $200 \mathrm{~m}$, from the "grand truth" at $1000 \mathrm{~m}, 500 \mathrm{~m}$, and $200 \mathrm{~m}$, from sampling at stall speed $\left(\mathrm{v}_{\min }\right)$ at $200 \mathrm{~m}$, and maximum speed $\left(\mathrm{v}_{\max }\right)$ at $200 \mathrm{~m}$ for prefrontal conditions on August 5 (first two rows of panel), conditions during the frontal passage on August 6 (middle two rows of panel) and after the front passed on August 7 (last two rows of panel). Panels show $20 \mathrm{~h}$ means for all sampling designs except for those using stall and maximum speed. Legend for August 7 differs from those for August 5 and 6. 


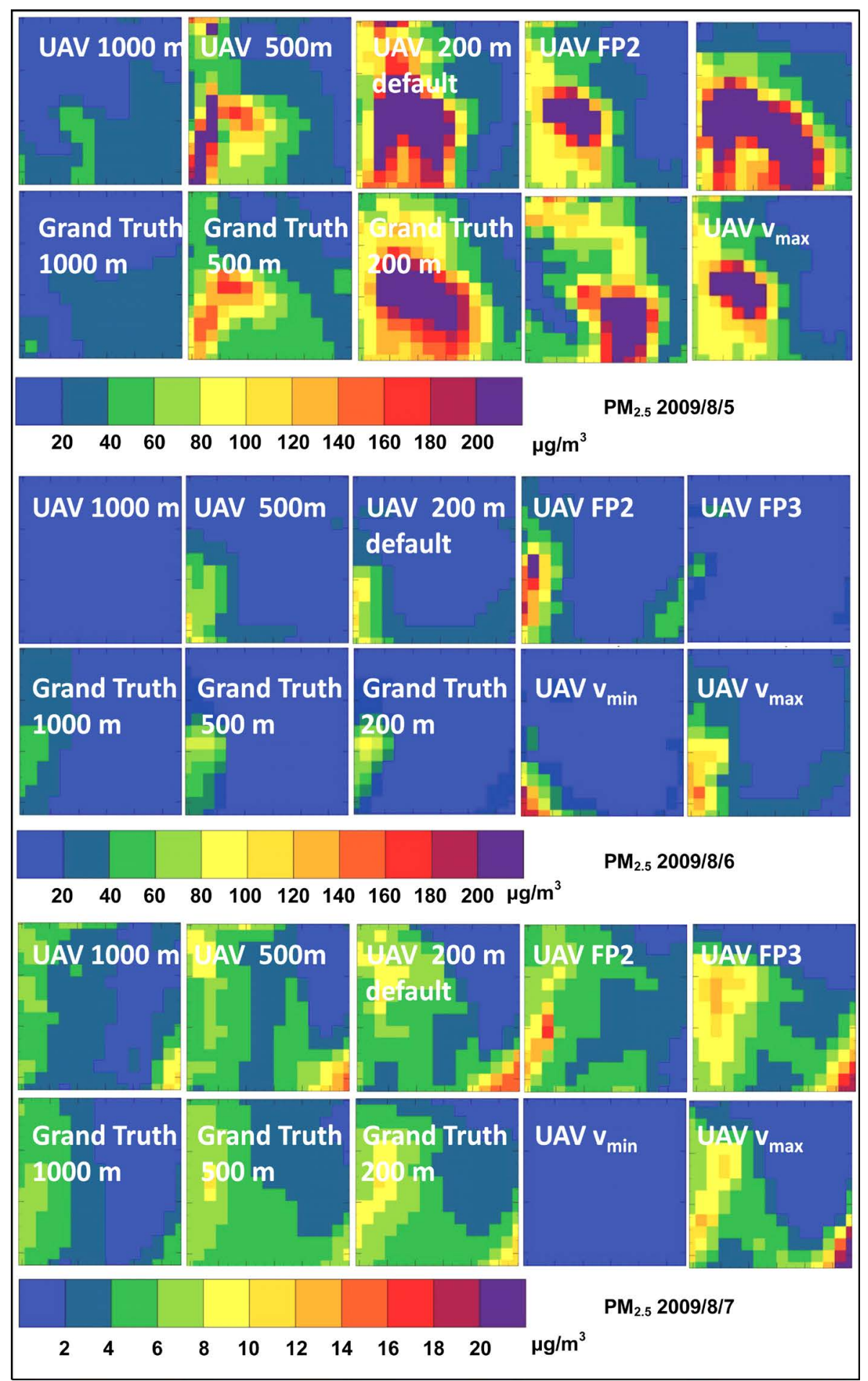

Figure 12. Distributions of mean $\mathrm{PM}_{2.5}$ concentrations as obtained (top left to bottom right) from virtual sampling at $1000 \mathrm{~m}, 500 \mathrm{~m}, 200 \mathrm{~m}$ (default), flight pattern 2 (FP2) at $200 \mathrm{~m}$, flight pattern 3 (FP3) at $200 \mathrm{~m}$, from the "grand truth" at $1000 \mathrm{~m}, 500 \mathrm{~m}$, and $200 \mathrm{~m}$, from sampling at stall speed $\left(\mathrm{v}_{\min }\right)$ at $200 \mathrm{~m}$, and maximum speed $\left(\mathrm{v}_{\max }\right)$ at $200 \mathrm{~m}$ for prefrontal conditions on August 5 (first two rows of panel), conditions during the frontal passage on August 6 (middle two rows of panel) and after the front passed on August 7 (last two rows of panel). Panels show $20 \mathrm{~h}$ means for all sampling designs except for those using stall and maximum speed. Legend for August 7 differs from those for August 5 and 6. 
The largest differences among the $20 \mathrm{~h}$ mean $\mathrm{PM}_{2.5}$ concentrations from sampling among each other and the "grand truth" occurred for stall speed (Figure 11). At cruising or maximum speed, the differences between the $20 \mathrm{~h}$ means from sampling showed more spatial variability than at stall speed. Independent of flight speed, the 20 h mean $\mathrm{PM}_{2.5}$ concentrations generally underestimated those of the "grand truth." Absolute mean fractional and normalized mean biases ranged from $2 \%$ to 66\%. At maximum (minimum) speed, the overall mean FB and NMB were $-2 \%(-66 \%)$ and $-21 \%(-48 \%)$, respectively.

$\mathrm{PM}_{10}$ also encompasses $\mathrm{PM}_{2.5}$. Comparison of $\mathrm{PM}_{10}$ and $\mathrm{PM}_{2.5}$ concentrations showed that PM with diameters between $2.5 \mu \mathrm{m}$ and $10 \mu \mathrm{m}$ occurred at all three flight levels at all times. Due to the size dependency of settling velocities and of thermodynamic behavior under high relative humidity conditions, PM can experience stratification [66]. To understand the consequences of this behavior for UAV sampling results we compared the findings for these aerosol size classes. Stratification occurred when clouds with low ceilings formed below $250 \mathrm{~m}$.

Typically, for both $\mathrm{PM}_{2.5}$ and $\mathrm{PM}_{10}$ concentrations decreased with increasing height except for four cases when PM accumulated at the top of the ABL due to inversions. $\mathrm{PM}_{10}$ and $\mathrm{PM}_{2.5}$ concentrations differed by about $0.1 \mu \mathrm{g} \cdot \mathrm{m}^{-3}$ which is about the uncertainty of current state-of-the-art measurements on the ground. This finding means that (a) the majority of the particulate matter was $\mathrm{PM}_{2.5}$ which is health adverse [69]; (b) concentrations of $\mathrm{PM}_{2.5}$ and $\mathrm{PM}_{10}$ were positively correlated independent of the choice of the flight pattern; (c) the same was true when the virtual UAV travelled at different speeds.

\section{Conclusions}

Our feasibility study theoretically examined whether UAVs could provide spatial distributions of mean pollutant concentrations suitable for public air-quality advisory. We used an episode during the 2009 Crazy Mountain fires in Interior Alaska as a test case.

Evaluated WRF/Chem data served to represent the conditions in the ABL and, hence, as "grand truth" in this study. A virtual Scan Eagle travelling at different heights, speeds and different patterns collected data from the WRF/Chem results along its flight path. We assumed optimum conditions with respect to flight duration, i.e. zero-weight payload and full fuel tank. Under such conditions, the Scan Eagle can fly about 20 h. The mean distributions derived from the sampled data were compared to the mean distributions according to the "grand truth." We examined a polluted situation with a fully developed wildfire-smoke plume, the removal of pollutants by a cold front passage, and the re-development of the smoke plumes. All quantities showed strong sensitivity to the flight patterns and heights on the day of the cold front passage.

Comparison of $20 \mathrm{~h}$ mean distributions obtained from sampling at different altitudes revealed the following: For air and dewpoint temperatures, differences were related to the environmental temperature lapse rate and the dewpoint temperature lapse rate, respectively. Concentrations of gases were nearly uniform with height under conditions of strong vertical mixing within the ABL.

In general, the virtual UAV captured the concentrations' reset to clean air background values after the cold front had passed the sampling domain, and the re-development of the plume thereafter. However, on the day of the frontal passage, $20 \mathrm{~h}$ mean distributions from sampling at different speeds and/or with different patterns led to different results and greater discrepancies from the 20 h means of the "grand truth" than found on the days prior to and after the frontal passage.

In the case of $\mathrm{CO}$, the 20 h spatio-temporal variability obtained from sampling agreed with the "grand truth" within a factor of two at $1000 \mathrm{~m}$, i.e. UAV sampling can provide good $20 \mathrm{~h}$ mean distributions of CO at $1000 \mathrm{~m}$ for $60 \mathrm{~km} \times 60 \mathrm{~km}$ and retrieve information on smoke-plume propagation. Based on the results for CO, one may conclude, that in general, some of the $20 \mathrm{~h}$ mean pollutant concentrations obtained by the different flight patterns were due to changes in wind direction.

For primary pollutants involved in photochemical reaction chains $\left(\mathrm{SO}_{2}, \mathrm{NO}\right)$ it is necessary to derive separate mean distributions for daytime and nighttime. The diurnal cycle of their concentrations led to overestimation (underestimation) of $20 \mathrm{~h}$ means in areas of high (low) concentrations as compared to the "grand truth." The unequal amount of daylight and dark hours and the time differences when the virtual UAV scanned a location caused that spatio-temporal biases did not cancel out.

Given the relative short darkness at high latitudes in late summer, the collection of enough nighttime data would require more than one UAV for coverage of the same area. Each UAV would have to fly a different sampling pattern for $20 \mathrm{~h}$. The choice of sampling patterns must ensure that during darkness, the different UAVs 
would collect data in different areas of the sampling domain. The shorter the darkness, the more UAVs would be required which might cause logistic and personnel difficulties. The collected data would have to be sorted to create separate daylight and nighttime mean distributions.

The $20 \mathrm{~h}$ mean distributions of gases involved in photochemistry differed among flight patterns except for $\mathrm{O}_{3}$. However, the $20 \mathrm{~h}$ mean $\mathrm{O}_{3}$ distribution obtained from sampling depended on the speed of the virtual UAV.

The lowest possible safe flight height and cruising speed would provide information on how the underlying landscape modulates the smoke plume. Sampling around the top of the ABL would provide information on the plume's dispersion and would be helpful for aviation advisory for small aircrafts when satellite imagery cannot provide this information due to a closed cloud cover in the mid- and upper troposphere. When deciding on the flight pattern, it is critical to consider wind speed, direction and precipitation, and their forecasted spatiotemporal evolutions during the planned flight duration. The sampling pattern must be designed to capture the conditions of interest (e.g. severity of pollution, washout due to frontal passage).

Sampling strategies for meteorological and chemical quantities might differ. Thus, air-quality forecasts and the virtual sampling technique introduced here may be an asset in effective, optimized flight planning, and collecting the data needed to answer the research question(s) at hand.

Our theoretical study assumed zero payload, i.e. a full tank. The heavier the payload the less fuel can be added, which reduces flight duration. While flight duration may be of low relevance for research questions related to short-term processes, deployment of UAVs for use in air-quality advisories requires a long flight duration to cover a large area in the downwind of the wildfire and for calculation of multi-hour means depending on the sampled species and its NAAQS averaging requirements. For some of the examined quantities, instruments light and small enough to fit in the UAV and that can sample at high enough frequency still have to be developed.

\section{Acknowledgements}

The authors wish to thank Uma S. Bhatt, R.L. Collins, M.C. Hatfield, D. Thorsen and the anonymous reviewers for fruitful discussion and helpful comments. The Research Support Center located at the Geophysical Institute of the University of Alaska Fairbanks provided CPU time and data storage. The National Aeronautics and Space Administration provided funding (Grant NASA-NNX11AQ27A).

\section{References}

[1] Elston, J., Argrow, B., Stachura, M., et al. (2014) Overview of Small Fixed-Wing Unmanned Aircraft for Meteorological Sampling. Journal of Atmospheric and Oceanic Technology, 32, 97-115. http://dx.doi.org/10.1175/JTECH-D-13-00236.1

[2] US Census Bureau (2015) National Population Projections. https://www.census.gov/population/projections/data/national/2014.html

[3] PaiMazumder, D. and Mölders, N. (2009) Theoretical Assessment of Uncertainty in Regional Averages Due to Network Density and Design. Journal of Applied Meteorology and Climatology, 48, 1643-1666. http://dx.doi.org/10.1175/2009JAMC2022.1

[4] Shulski, M. and Wendler, G. (2007) The Climate of Alaska. University of Alaska Press, Fairbanks, 216 p.

[5] Bienek, P. (2007) Climate and Predictability of Alaska Wildfires. Master's Thesis, Department of Atmospheric Sciences, University of Alaska Fairbanks, Fairbanks, 95 p.

[6] Mölders, N. and Kramm, G. (2007) Influence of Wildfire Induced Land-Cover Changes on Clouds and Precipitation in Interior Alaska-A Case Study. Atmospheric Research, 84, 142-168. http://dx.doi.org/10.1016/j.atmosres.2006.06.004

[7] Mölders, N. (2008) Suitability of the Weather Research and Forecasting (WRF) Model to Predict the June 2005 Fire Weather for Interior Alaska. Weather and Forecasting, 23, 953-973. http://dx.doi.org/10.1175/2008WAF2007062.1

[8] Butwin, M.K. (2015) Theoretical Investigations on Strategies for Sampling Meteorological and Chemical Field Quantities in Smoke Plumes Using UAVs. Master's Thesis, Department of Atmospheric Sciences, University of Alaska Fairbanks, Fairbanks, 176 p.

[9] Mayer, S., Sandvik, A., Jonassen, M.O. and Reuder, J. (2010) Atmospheric Profiling with the UAS SUMO: A New Perspective for the Evaluation of Fine-Scale Atmospheric Models. Meteorology and Atmospheric Physics, 63, 15-26.

[10] Skamarock, W.C., Klemp, J.B., Dudhia, J., et al. (2008) A Description of the Advanced Research WRF Version 3. NCAR/TN, 125 p.

[11] Elston, J.S., Roadman, J., Stachura, M., et al. (2011) The Tempest Unmanned Aircraft System for in Situ Observations 
of Tornadic Supercells: Design and VORTEX2 Flight Results. Journal of Field Robotics, 28, 461-483. http://dx.doi.org/10.1002/rob.20394

[12] Patterson, M.C.L., Mulligan, A., Douglas, J., et al. (2005) Volcano Surveillance by ACR Silver Fox. American Institute of Aeronautics and Astronautics, 1, 26-29. http://dx.doi.org/10.2514/6.2005-6954

[13] McGonigle, A.J.S., Aiuppa, A., Giudice, G., et al. (2008) Unmanned Aerial Vehicle Measurements of Volcanic Carbon Dioxide Fluxes. Geophysical Research Letters, 35, Article ID: L06303. http://dx.doi.org/10.1029/2007gl032508

[14] EPA (2011) National Ambient Air Quality Standards (NAAQS). http://www.epa.gov/air/criteria.html

[15] Grell, G.A., Peckham, S.E., Schmitz, R., et al. (2005) Fully Coupled “Online” Chemistry within the WRF Model. Atmospheric Environment, 39, 6957-6975. http://dx.doi.org/10.1016/j.atmosenv.2005.04.027

[16] Peckham, S.E., Fast, J., Schmitz, R., et al. (2011) WRF/Chem Version 3.3 User's Guide. 96 p.

[17] Mlawer, E.J., Taubman, S.J., Brown, P.D., Iacono, M.J. and Clough, S.A. (1997) Radiative Transfer for Inhomogeneous Atmospheres: RRTM, a Validated Correlated-K Model for the Longwave. Journal of Geophysical Research, 102D, 16663-16682. http://dx.doi.org/10.1029/97JD00237

[18] Chou, M.-D. and Suarez, M.J. (1994) An Efficient Thermal Infrared Radiation Parameterization for Use in General Circulation Models. Report, Goddard Space Flight Center, Greenbelt, 85 p.

[19] Grell, G.A. and Dévényi, D. (2002) A Generalized Approach to Parameterizing Convection. Geophysical Research Letters, 29, 1693.

[20] Lin, Y.-L., Rarley, R.D. and Orville, H.D. (1983) Bulk Parameterization of the Snow Field in a Cloud Model. Journal of Applied Meteorology, 22, 1065-1092. http://dx.doi.org/10.1175/1520-0450(1983)022<1065:BPOTSF>2.0.CO;2

[21] Barnard, J., Fast, J., Paredes-Miranda, G., Arnott, W. and Laskin, A. (2010) Technical Note: Evaluation of the WRF-Chem “Aerosol Chemical to Aerosol Optical Properties” Module Using Data from the MILAGRO Campaign. Atmospheric Chemistry and Physics, 10, 7325-7340. http://dx.doi.org/10.5194/acp-10-7325-2010

[22] Grell, G.A., Freitas, S.R., Stuefer, M. and Fast, J.D. (2011) Inclusion of Biomass Burning in WRF-Chem: Impact on Wildfires on Weather Forecasts. Atmospheric Chemistry Physics, 11, 5289-5303. http://dx.doi.org/10.5194/acp-11-5289-2011

[23] Mellor, G.L. and Yamada, T. (1982) Development of a Turbulence Closure Model for Geophysical Fluid Problems. Review of Geophysics—Space Physics, 20, 851-875. http://dx.doi.org/10.1029/RG020i004p00851

[24] Janjić, Z.I. (1994) The Step-Mountain Eta Coordinate Model: Further Developments of the Convection, Viscous Sublayer and Turbulence Closure Schemes. Monthly Weather Review, 122, 927-945. http://dx.doi.org/10.1175/1520-0493(1994)122<0927:TSMECM>2.0.CO;2

[25] Smirnova, T.G., Brown, J.M., Benjamin, S.G. and Kim, D. (2000) Parameterization of Cold Season Processes in the Maps Land-Surface Scheme. Journal Geophysical Research, 105D, 4077-4086. http://dx.doi.org/10.1029/1999JD901047

[26] Stockwell, W.R., Middleton, P., Chang, J.S. and Tang, X. (1990) The Second-Generation Regional Acid Deposition Model Chemical Mechanism for Regional Air Quality Modeling. Journal Geophysical Research, 95, 16343-16367. http://dx.doi.org/10.1029/JD095iD10p16343

[27] Madronich, S. (1987) Photodissociation in the Atmosphere, 1, Actinic Flux and the Effects of Ground Reflections and Clouds. Journal Geophysical Research, 92, 9740-9752. http://dx.doi.org/10.1029/JD092iD08p09740

[28] Wesely, M.L. (1989) Parameterization of Surface Resistances to Gaseous Dry Deposition in Regional-Scale Numerical Models. Atmospheric Environment, 23, 1293-1304. http://dx.doi.org/10.1016/0004-6981(89)90153-4

[29] Mölders, N., Tran, H.N.Q., Quinn, P., et al. (2011) Assessment of WRF/Chem to Capture Sub-Arctic Boundary Layer Characteristics during Low Solar Irradiation Using Radiosonde, Sodar, and Station Data. Atmospheric Pollution Research, 2, 283-299. http://dx.doi.org/10.5094/APR.2011.035

[30] Ackermann, I.J., Hass, H., Memmesheimer, M., Ziegenbein, C. and Ebel, A. (1995) The Parametrization of the SulfateNitrate-Ammonia Aerosol System in the Long-Range Transport Model EURAD. Meteorology and Atmospheric Physics, 57, 101-114. http://dx.doi.org/10.1007/BF01044156

[31] Ackermann, I.J., Hass, H., Memmesheimer, M., et al. (1998) Modal Aerosol Dynamics Model for Europe: Development and First Applications. Atmospheric Environment, 32, 2981-2299. http://dx.doi.org/10.1016/S1352-2310(98)00006-5

[32] Kramm, G., Beheng, K.-D. and Müller, H. (1992) Vertical Transport of Polydispersed Aerosol Particles in the Atmospheric Surface Layer. In: Schwartz, S.E. and Slinn, W.G.N., Eds., Precipitation Scavenging and Atmosphere-Surface Exchange Processes, Vol. 2, Hemisphere Publishing Company, Washington/Philadelphia/London, 1125-1141.

[33] Schell, B., Ackermann, I.J., Hass, H., Binkowski, F.S. and Ebel, A. (2001) Modeling the Formation of Secondary Organic Aerosol within a Comprehensive Air Quality Model System. Journal of Geophysical Research, 106, 28275- 
28293. http://dx.doi.org/10.1029/2001JD000384

[34] Freitas, S.R., Longo, K.M., Alonso, M.F., et al. (2011) Prep-Chem-SRC-1.0: A Preprocessor of Trace Gas and Aerosol Emission Fields for Regional and Global Atmospheric Chemistry Models. Geoscientific Model Development, 4, 419-433. http://dx.doi.org/10.5194/gmd-4-419-2011

[35] NASA EOSDIS (2012) Near Real-Time Data. http://lance-modis.eosdis.nasa.gov/imagery/subsets/?area=global

[36] Olson, J., Watts, S. and Allison, L.J. (2000) Major World Ecosystem Complexes Ranked by Carbon in Live Vegetation: A Database (Revised November 2000). Carbon Dioxide Information Analysis Center, Oak Ridge National Laboratory, Oak Ridge.

[37] van Aardenne, J.A., Dentener, F., Olivier, J.G.J. and Peters, J.A.H.W. (2005) The EDGAR 3.2 Fast Track 2000 Dataset. (32FT2000)

[38] Mölders, N. (2010) Alaska Emission Model (AkEM)—Version 1.01 Description. Internal Report, Fairbanks, 16 p.

[39] Guenther, A., Hewitt, C., Erickson, D., et al. (1994) A Global Model of Natural Volatile Organic Compound Emissions. Journal Geophysical Research, 100D, 8873-8892.

[40] Simpson, D., Guenther, A., Hewitt, C.N. and Steinbrecher, R. (1995) Biogenic Emissions in Europe 1. Estimates and Uncertainties. Journal Geophysical Research, 100D, 22875-22890. http://dx.doi.org/10.1029/95JD02368

[41] Department of Commerce (2000) NCEP FNL Operational Model Global Tropospheric Analyses, Continuing from July 1999. Research Data Archive at the National Center for Atmospheric Research, Computational and Information Systems Laboratory. http://rda.ucar.edu/datasets/ds083.2/

[42] Sassen, K. (1991) The Polarization Lidar Technique for Cloud Research: A Review and Current Assessment. Bulletin of the American Meteorologlogical Society, 72, 1848-1866. http://dx.doi.org/10.1175/1520-0477(1991)072<1848:TPLTFC>2.0.CO;2

[43] Mishchenko, M.I. and Sassen, K. (1998) Depolarization of Lidar Returns by Small Ice Crystals: An Application to Contrails. Geophysical Research Letters, 25, 309-312. http://dx.doi.org/10.1029/97GL03764

[44] Sassen, K. (2000) Lidar Backscatter Depolarization Technique for Cloud and Aerosol Research. In: Mishchenko, M.I., Hovenier, J.W. and Travis, L.D., Eds., Light Scattering by Nonspherical Particles, Academic Press, San Diego, 393416. http://dx.doi.org/10.1016/B978-012498660-2/50041-0

[45] Sassen, K. (2005) Dusty Ice Clouds over Alaska. Nature, 434, 456. http://dx.doi.org/10.1038/434456a

[46] Madden, J.M. (2014) Using WRF/Chem, In-Situ Observations, and CALIPSO Data to Simulate Smoke Plume Signatures on High-Latitude Pixels. Master's Thesis, Department of Atmospheric Sciences, University of Alaska Fairbanks, Fairbanks, 106 p.

[47] Madden, J.M., Mölders, N. and Sassen, K. (2015) Assessment of WRF/Chem Simulated Vertical Distributions of Particulate Matter from the 2009 Minto Flats South Wildfire in Interior Alaska by CALIPSO Total Backscatter and Depolarization Measurements. Open Journal of Air Pollution, 4, 119-138. http://dx.doi.org/10.4236/ojap.2015.43012

[48] Sassen, K. (2008) Boreal Tree Pollen Sensed by Polarization Lidar: Depolarizing Biogenic Chaff. Geophysical Research Letters, 35, Article ID: L18810. http://dx.doi.org/10.1029/2008gl035085

[49] Martins, J.V., Hobbs, P.V., Weiss, R.E. and Artaxo, P. (1998) Sphericity and Morphology of Smoke Particles from Biomass Burning in Brazil. Journal of Geophysical Research-Atmosphere, 103, 32051-32057. http://dx.doi.org/10.1029/98JD01153

[50] Murayama, T., Müller, D., Wada, K., et al. (2004) Characterization of Asian Dust and Siberian Smoke with MultiWavelength Raman Lidar over Tokyo, Japan in Spring 2003. Geophysical Research Letters, 31, Article ID: L23103. http://dx.doi.org/10.1029/2004GL021105

[51] Sassen, K. (2008) Identifying Atmospheric Aerosols with Polarization Lidar. In: Kim, Y.J. and Platt, U., Eds., Advanced Environmental Modeling, Springer Science + Business Media Inc., New York, 136-142. http://dx.doi.org/10.1007/978-1-4020-6364-0_10

[52] Wandinger, U., Müller, D., Böckmann, C., et al. (2002) Optical and Microphysical Characterization of BiomassBurning and Industrial-Pollution Aerosols from Multiwavelength Lidar and Aircraft Measurements. Journal of Geophysical Research, 107, 8125-8145. http://dx.doi.org/10.1029/2000JD000202

[53] Lee, C.H., Kim, J.H., Park, C.B., et al. (2004) Continuous Measurements of Smoke of Russian Forest Fire by 532/1064 $\mathrm{nm}$ Mie Scattering Lidar at Suwon, Korea. In: Proceedings of the 22nd International Laser Radar Conference, European Space Agency, Paris, 535-538.

[54] Hu, Y.M., Vaughan, M., Liu, Z., et al. (2007) The Depolarization—Attenuated Backscatter Relation: CALIPSO Lidar Measurements vs. Theory. Optical Express, 15, 5327-5332. http://dx.doi.org/10.1364/OE.15.005327

[55] Chang, J.C. and Hanna, S.R. (2004) Air Quality Model Performance Evaluation. Meteorology and Atmospheric Physics, 87, 167-196. http://dx.doi.org/10.1007/s00703-003-0070-7 
[56] EPA (2007) Guidance on the Use of Models and Other Analyses for Demonstrating Attainment of Air Quality Goals for Ozone, $\mathrm{PM}_{2.5}$, and Regional Haze. 262 p. http://www3.epa.gov/scram001/guidance/guide/final-03-pm-rh-guidance.pdf

[57] Appel, K., Roselle, S., Gilliam, R. and Pleim, J. (2010) Sensitivity of the Community Multiscale Air Quality (CMAQ) Model v4.7 Results for the Eastern United States to MM5 and WRF Meteorological Drivers. Geoscience Model Development, 3, 169-188. http://dx.doi.org/10.5194/gmd-3-169-2010

[58] Hines, K.M. and Bromwich, D.H. (2008) Development and Testing of Polar Weather Research and Forecasting (WRF) Model. Part I: Greenland Ice Sheet Meteorology. Monthly Weather Review, 136, 1971-1989. http://dx.doi.org/10.1175/2007MWR2112.1

[59] Hines, K.M., Bromwich, D.H., Bai, L.-S., Barlage, M. and Slater, A.G. (2011) Development and Testing of Polar WRF. Part III. Arctic Land. Journal of Climate, 24, 26-48. http://dx.doi.org/10.1175/2010JCLI3460.1

[60] Avissar, R. and Pielke, R.A. (1989) A Parameterization of Heterogeneous Land Surface for Atmospheric Numerical Models and Its Impact on Regional Meteorology. Monthly Weather Review, 117, 2113-2136. http://dx.doi.org/10.1175/1520-0493(1989)117<2113:APOHLS>2.0.CO;2

[61] Mölders, N. and Raabe, A. (1996) Numerical Investigations on the Influence of Subgrid-Scale Surface Heterogeneity on Evapotranspiration and Cloud Processes. Journal of Applied Meteorology, 35, 782-795. http://dx.doi.org/10.1175/1520-0450(1996)035<0782:NIOTIO>2.0.CO;2

[62] Mölders, N., Tran, H.N.Q., Cahill, C.F., Leelasakultum, K. and Tran, T.T. (2012) Assessment of WRF/Chem PM 2.5 Forecasts Using Mobile and Fixed Location Data from the Fairbanks, Alaska Winter 2008/09 Field Campaign. Air Pollution Research, 3, 180-191. http://dx.doi.org/10.5094/apr.2012.018

[63] Pirhalla, M.A., Gende, S. and Mölders, N. (2014) Fate of Particulate Matter from Cruise-Ship Emissions in Glacier Bay during the 2008 Tourist Season. Journal of Environmental Protection, 4, 1235-1254. http://dx.doi.org/10.4236/jep.2014.512118

[64] von Storch, H. and Zwiers, F.W. (1999) Statistical Analysis in Climate Research. Cambridge University Press, Cambridge, $484 \mathrm{p}$.

[65] Mölders, N. and Kramm, G. (2014) Lectures in Meteorology. Heidelberg, Springer, 591 p.

[66] Seinfeld, J.H. and Pandis, S.N. (1997) Atmospheric Chemistry and Physics, from Air Pollution to Climate Change. John Wiley \& Sons, New York, 1326 p.

[67] Hanna, S. and Chang, J. (2012) Acceptance Criteria for Urban Dispersion Model Evaluation. Meteorology and Atmospheric Physics, 116, 133-146. http://dx.doi.org/10.1007/s00703-011-0177-1

[68] Freitas, S.R., Longo, K.M., Silva Dias, M.A.F. and Artaxo, P. (1996) Numerical Modeling of Air Mass Trajectories from the Biomass Burning Areas of the Amazon Basin. Annals of the Brazilian Academy of Sciences, 68, 193-206.

[69] Pope, I.C.A., Dockery, D.W. and Schwartz, J. (1995) Review of Epidemiological Evidence of Health Effects of Particulate Air Pollution. Inhalation Toxicology, 7, 1-18. http://dx.doi.org/10.3109/08958379509014267 